\title{
A Recent Advances in Use of Plant Growth Regulators (PGRs) in Fruit Crops - A Review
}

\author{
Tejpal Singh Bisht ${ }^{1}$, Laxmi Rawat ${ }^{1}$, Binayak Chakraborty ${ }^{2}$ and Vikas Yadav $^{3 *}$
}
${ }^{1}$ College of Forestry, Ranichauri, VCSG Uttarakhand University of Horticulture and Forestry, Bharsar-249 199 (Pauri), Uttarakhand, India
${ }^{2}$ College of Agriculture, Navasri Agricultural University, Waghai- 394730 (The Dangs), Gujarat, India
${ }^{3}$ Central Horticultural Experimental Station (ICAR), Vejjalpur (Godhra), Gujarat, India

*Corresponding author

\begin{tabular}{|l|}
\hline Ke y w or d s \\
Plant Growth \\
Regulators (PGRs), \\
Fruit crops \\
\hline Article Info \\
\hline $\begin{array}{l}\text { Accepted: } \\
\text { 12 April } 2018 \\
\text { Available Online: } \\
\text { 10 May } 2018\end{array}$ \\
\hline
\end{tabular}

\section{A B S T R A C T}

Plant growth regulators or phytohormones are organic substances produced naturally in higher plants, controlling growth or other physiological functions at a site remote from its place of production and active in minute amounts. The discovery of plant hormones and their ability to regulate all aspects of plant growth and development were defining moments in horticulture. Plant Growth Regulators (PGRs) were soon identified that could improve yield, quality and postharvest life. Nowhere has their impact been more vividly chronicled than in tree fruit production. Tree fruit are considered high value crops and even small modifications in production efficiency, product quality or enhanced cosmetic appeal have the potential to significantly increase product value. Following the discovery of auxins, NAA was found to both to useful in counteract two of the most serious problems of apple production, biennial bearing and preharvest drop. NAA continues to be an important PBR. The discovery of gibberellins and cytokinins led to commercial uses of products in these hormone categories that include improved shape of fruit, enhanced market value by reducing blemishes, optimise tree architecture that may be accomplished the by overcoming apical dominance. PBRs were later discovered that could either advance ripening or extend postharvest life, thus greatly expanding the effective period when high quality fruit could be harvested and marketed. Other areas of fruit production where PBRs are especially useful include prevention of preharvest fruit drop, control of vegetative growth, enhanced flower bud formation and control of fruit ripening. Some other PBRs like Prohaxadione calcium, an inhibitor of gibberellin biosynthesis, not only retarded shoot growth but it can also alter plant metabolism to impart resistance to insects and diseases. The naturally occurring hormone abscisic acid is showing potential for overcoming plant stress and also enhancing early fruit drop. Recently 1-MCP, a competitive inhibitor of ethylene, has revolutionized storage of pome fruit by extending the postharvest life and improving storage quality of fruit. Today's great progress in PBR use has come in areas of fruit thinning and retardation of preharvest drop. In these areas greater understanding of fundamental processes, the use of molecular biology techniques and continued empirical research has lead to more effective control of these important process in tree fruit production. 


\section{Introduction}

Plant growth regulators (PGRs) or phytohormones are organic compounds, other than nutrients, that produced naturally in higher plants, controlling growth or other physiological functions at a site remote from its place of production and active in minute amounts, modify plant physiological process. PGRs called biostimulats or bioinhibitors, act inside plant cells to stimulate or inhibit specific enzymes or enzymes systems and help regulate plant metabolism. They normally are active at very low concentrations in plants. Plant growth regulators generally include auxins, gibberellins, cytokinins, ethylene, growth retardants and growth inhibitors. Auxins are the hormones first discovered in plants and later gibberellins and cytokinins were also discovered. Thimann (1963) designated the plant hormones by the term 'phytohormones' (as these hormones are synthesized in plants) in order to distinguish them from animal hormones. He defined a phytohormone as "an organic compound produced naturally in higher plants, controlling growth or other physiological functions at a site remote from its place of production and active in minute amounts."

A definition of plant hormones with still wider scope has been given by Van Overbeek et al., (1941). According to him, the plant hormones are defined as "organic compounds which regulate plant physiological processregardless of whether these compounds are naturally occurring and/or synthetic; stimulating and/or inhibitory; local activators or substances which act at a distance from the place where they are formed."

\section{Plant hormone}

It is restricted to naturally occurring plant substances, there fall into five classes. Auxin, Gibberellins, Cytokinin, ABA and ethylene.
Plant growth regulator includes synthetic compounds as well as naturally occurring hormones.

\section{Plant growth hormone}

The primary site of action of plant growth hormones at the molecular level remains unresolved.

\section{Reasons}

Each hormone produces a great variety of physiological responses.

Several of these responses to different hormones frequently are similar.

The response of a plant or a plant part to plant growth regulators may vary with the variety of the plant.

Even a single variety may respond differently depending on its age, environmental conditions and physiological state of development (especially its natural hormone content) and state of nutrition. There are always exceptions for a general rule suggesting the action of a specific growth regulator on plants.

There are several proposed modes of action in each class of plant hormone, with substantial arguments for and against each mode.

The importance of PGRs was first recognized in the 1930s. Since that time, natural and synthetic compounds that alter function, shape and size of crop plants have been discovered. Today, specific PGRs are used to modify crop growth rate and growth pattern during the various stages of development from germination through harvest and post-harvest preservation. Growth regulating chemicals that have positive influences on major agronomic crops can be of value. 


\section{Classes of plant growth regulators}

\section{Growth promoters}

The plant-bio regulators or hormones which have catalytical effect, i.e. take a vital role in plant growth are called growth promoter e.g. Auxins, Gibberellins and Cytokinins.

\section{Auxins}

Auxins are a group of phytohormones produced in the shoot and root apices and they migrate from the apex to the zone of elongation. Auxins promote the growth along the longitudinal axis of the plant and hence the name (auxeing: to grow or to increase). The term, auxin was introduced by Kogl and Haagen- Smit (1931) designating those plant hormones which are especially concerned with cell enlargement or the growth of the shoots. Went (1926 and 1928) isolated auxin from the Avena coleoptile tips by a method called Avena coleoptile or curvature test and concluded that no growth can occur without auxin. Auxins are widely distributed throughout the plant however, abundant in the growing tips such as coleoptile tip, buds, root tips and leaves. Indole Acetic Acid (IAA) is the only naturally occurring auxin in plants. An auxin may, thus, be defined as "an organic substance which promotes growth (i.e., irreversible increase in growth) along the longitudinal axis when applied in low concentrations to shoots of the plants freed as far as practicable from their own inherit growth promoting substances. Auxins may, and generally do, have other properties but this one is critical" (Thimann, 1963). At low concentration, they (auxin) stimulate growth while at high concentration they retard growth. They are characterized by causing cell enlargement and stem elongation in plants. They are also active in development of branches in plants and are associated with apical dominance.

\section{Physiological effects of auxins}

It was previously thought that the sole function of auxins was to promote cell enlargement. But the work done in later years has proved them to be deeply associated with a variety of functions. In some cases they act as a stimulating agent, in others as an inhibitory agent and in still others as a necessary participant in the growth activity of other phytohormones such as gibberellins and cytokinins. The various growth processes in which the auxins (both natural and synthetic) play their role are in listed below.

\section{Gibberellin}

The gibberellins were discovered in an interesting and incidental way. In early part of the twentieth century, Japanese farmers Kurosawa noted that some plants in rice fields were taller, thinner and paler than the normal plants; had longer and narrower leaves markedly overgrowing their unaffected neighbours; and were sometimes devoid of fruits too.

They named this disease as "bakanae", meaning foolish seedlings. Sawada (1912) suggested that the disease is due to a 'substance' secreted by a parasitic as comycetous fungus, Gibberella fujikuroi (the perfect form, occurring only occasionally; the imperfect form is Fusarium moniliforme, in infecting the diseased plants. This suggestion was experimentally supported by Kurosawa (1926) who demonstrated that sterile filtrates of the fungus could initiate symptoms of bakanae disease in healthy rice seedlings.

Later in Yabuta (1935) and Yabuta and Hayashi (1939) isolated this growth promoting substance in crystalline form and named it as gibberellin $\mathrm{A}$, which has now been shown as a mixture of many growth promoters, collectively known as gibberellins. 
Since that time, gibberellins and allied substances have been found in higher plants also by Mitchell and Angel (1951), West (1973) and Sumiki et al., (1953). A gibberellin (abbreviated as GA, for gibberellic acid) may be defined as a compound which is active in gibberellin bioassays and possesses a gibbane ring skeleton. There are, however, other compounds (like kaurene) which are active in some of the assays but do not possess a gibbane ring. Such compounds have been called gibberellin-like rather than gibberellins. The best known of gibberellins is Gibberellic acid (i.e. $\mathrm{GA}_{3}$ ).

\section{Physiological effects of gibberellins}

\section{Cytokinins}

The word for cytokinins is a generic name for all naturally occurring substances that are known to promote cell division. The term, cytokinin was proposed by Letham (1963). They are also known to delay senescence. The first naturally occurring cytokinin was found in corn and is referred as zeatin.

The most widely distributed cytokinins are the synthetic benzyladenine and kinetin. Kinetin was discovered from the tobacco pith callus and the chemical substance was identified as 6-furfuryl aminopurine. The natural cytokinin appears to be made principally in apical root meristem, inflorescences and developing fruits.

Certain cytokinins have been found to be the constituent of certain transfer RNA molecules in a number of different organisms. They are also involved in stimulation of organ formation e.g. formation of leave, fruit, buds, and branches. They tend to contract or overcome apical dominance and break dormancy. They also enhance seed germination and uniform flowering. Cytokinins regulate the transportation of metabolites in the phloem. Cytokinins are also useful in the preservation of flowers, fruits and leafy vegetables.

\section{Physiological effects of cytokinins}

\section{Growth inhibitors}

The plant bio-regulators which selectively interfere with normal hormonal promotion of growth are called Growth Inhibitor e.g. Abscisic acid and Ethylene.

\section{Abscisic acid (ABA)}

These were previously called Dormin or Abscisin mainly because of their regulatory effect on abscission and dormancy. This hormone is widespread in higher plants and is found in many different organs and tissues (both old and young) of plants. ABA induces abscission of the leaves of a wide variety of plants and fruits of some plant species.

ABA appears to be an internal factor inducing dormancy in the buds of at least some temperature zone woody plants.

ABA also prevents or delays the germination of seeds. ABA retards the growth of a large variety of plant tissues and organs including leaves, coleoptiles, stems, hypocotyls and roots. It promotes senescence through leaf abscission, degeneration of excised leaves and acceleration of decomposition of chlorophyll.

\section{Physiological effects of Abscisic acid (ABA)}

\section{Ethylene}

This is a simple gas that is produced in small quantities by many plant tissues and they serve as a very powerful regulator of growth and development. They are found very prominently in physiologically matured fruits undergoing ripening. 


\section{Physiological effects of ethylene}

\section{Growth retardants}

These are the synthetic organic compounds causing retardation of cell division by inhibiting biosynthesis of plant hormones without evocating substantial growth distortions e.g. onium compounds, pyrimidines, trizoles, tetcyclacis, morphactins, maleic hydrazide etc

Growth retardants which inhibit GAs biosynthesis

Several synthetic compounds, known as growth retardants, inhibit stem elongation by inhibiting GAs biosynthesis. GAs biosynthesis inhibitors fall into three classes.

Onium compounds such as quaternary ammonium (e.g. chlormequat chloride or CCC, mepiquat chloride and AMO-1618) and phosphonium compounds (e.g. chlorphonium chloride) blocks the synthesis of ent-kaurene. AMO-1618 and CCC specifically inhibit the activity of copalyl diphosphate synthase and to a lesser extent that of ent-kaurene synthase.

The second class consists of nitrogen containing heterocyclic compounds, such as ancymidol (pyrimidine), tetcyclacis (norbornanodiazetine) and trizole type compounds (e.g. paclobutrazol, uniconazole). These compounds inhibit the oxidation of entkaurene to ent-kaurenoic acid by P450 monooxygenases.

The third group includes acylcyclohexanediones, which inhibit the 2oxoglutarate dependent dioxygenases in $\mathrm{GA}_{\mathrm{s}}$ biosynthesis. Acylcyclohexanediones, such as prohexadione-Ca and trinexapac-ethyl (a salt and an ester, respectively) are structurally similar to 2-oxoglutarate and are inhibit dioxygenase activity by competing for the binding site for the cosubstrate, 2- oxoglutarate.

Growth retardants which not inhibits GAs biosynthesis

Morphactins (fluorene, fluorene-9-carboxylic acid and chlorfluorenol): These are derivatives of fluorene-9-carboxylic acid, which has a fluorene nucleus. These compounds may exert their effect by influencing the plant's auxin metabolism, thus causing alterations in hormonal control and such consequent responses as loss of apical dominance. These compounds are useful to control the growth of woody plants, but they have been known to cause foliar distortions, retardation of stem elongation and breaking of axillary bud. It also stimulate abscission of flowers and fruits because the firmness of attachment of fruit to the plant can be decreased by application of morphactins, they may become useful aids in the mechanical harvesting of grapes and tree fruits.

Maleic hydrazide: It is incorporated into the nucleolus as a part of the RNA fraction and it blocks the cell division by interfering with the production of uracil. It is a general inhibitor of meristematic activity, it retards stem elongation and prevents leaf and flower initiation, as well as fruit set and enlargement.

Role of growth retardants in growth promotion and inhibition

Inhibit excessive vegetative growth and promote reproductive growth

Enhance flowering and fruiting

Control irregular or alternate bearing

Induce early maturity

Promote ripening

Inhibit biosynthesis of plant hormones 


\section{Discovery of plant hormones}

The purpose of this communication is to chronicle and provide an overview of the development and use of plant bioregulators (PBRs) in tree fruit production. This has been and continues to be an evolving process. Since specific auxins were the first PBRs the history of the discovery and development must begin with auxins.

\section{Auxin}

Events leading to the discovery of auxin can be traced back to work done by Charles Darwin in the 1880s when he was trying to find the reason why plants bend toward light. $\mathrm{He}$ found that the tip of a coleoptile sensed light and there was a diffusible substance produced there that caused the shaded side to grow more rapidly than the illuminated side (Jacobs, 1979). Many others such as BoysenJensen, Paal, and Went in the early 1900s contributed to the body of information which eventually resulted in the discovery of the first plant hormone group auxins. IAA was identified from lower plants in the 1930s and finally from higher plants in the early 1940s (Thimann, 1969). This pathway to auxin discovery spanned 50 years. Valuable lessons were learned related to extraction, purification and detection which, coupled with methodology advancements, made the pathway to discovery and identification much shorter for the other plant hormones. The research with auxins in the 1930s can be considered the start of PBR research.

\section{Gibberellins}

The discovery of gibberellins can be traced back to Japanese pathologist in the 1920s who studied the foolish rice disease, a disease that caused rice plants to grow so rapidly that stems were too weak resulting in lodging. The cause of this exaggerated growth was determined to be the production of a growth stimulating substance produced by the fungus Gibberellia fujikuroi. Impure crystals containing a mixture of active ingredients were isolated in the late 1930s (Phinney, 1983). This information, and the significance of the discovery, did not surface until the 1950s because the information was published in Japanese in Japanese journals and there was a lack of exchange of information with the western world that was associated with World War II. Gibberellic acid was identified, crystallized and synthesized in the 1950s (Brian and Hemming, 1955).

\section{Cytokinins}

The discovery of cytokinins can be traced back to activities in the lab of Folke Skoog at the University of Wisconsin in the late 1940s. Skoog and Miller were studying cell division factors using a tobacco pith callus culture system. Cell division factors were found in coconut milk and yeast extracts and analysis of the active region on chromatograms suggested that the active factor was a purine (Jablonski and Skoog, 1954). All known purines were tested and found to be inactive, but degraded herring sperm DNA yielded significant activity. The active factor was finally identified and called Kinetin, but it was found to be a breakdown product of the DNA and not a naturally occurring compound (Miller et al., 1955). Armed with success, biological activity and a system for detecting biological activity, Zeatin was isolated from immature corn kernels by Letham in 1963 (Letham, 1963).

\section{Ethylene}

The growth regulation properties of ethylene were first noted by Nejublov in 1901 who reported that leaf abscission could be stimulated by coal gas. Subsequently, Denny and Miller in 1935 reported that ethylene 
could break dormancy, advance fruit ripening, stimulate flowering in pineapple, and was naturally produced by many organs in the plant, respectively (Abeles, 1973). Crocker et al., (1935) suggested that ethylene was an endogenous hormone. The assertion that ethylene should be elevated to hormonal status was largely dismissed by the scientific community. It was difficult to fathom how a two carbon compound floating freely in the air could be seriously considered to be a hormone. It was not until 1959 when the gas chromatograph was adopted as the primary way to quantify endogenous ethylene, that the physiological significance and importance of ethylene was recognized. Ethylene was then elevated to hormonal status (Burg and Thimann, 1959).

\section{Abscisic acid}

Abscisic acid (ABA) was the last major hormone to be identified, although its existence had been forecast for some time. Groups lead by Addicott studying hormonal relationships in cotton (Ohkuma et al., 1963) and Wareing studying dormancy in woody perennials independently identified Abscisin II in cotton and Dormin in woody plants (Corniforth et al., 1965). The two compounds were ultimately determined to be identical and were given the name Abscisic acid in 1967 at a plant hormone conference in Ottawa, Canada.

\section{PGR uses in tree fruit production}

PBRs are used more extensively in tree fruit production than in any other horticultural or agricultural commodity, and they are essential for effective and profitable production. Several commercial uses have been selected to illustrate the evolution of the involvement of PBRs from infancy to the present and progress made in the fundamental understanding of how regulation by PBRs is achieved.

\section{Role of PGRs in fruit abscission - pre- harvest drop}

Fruit abscission is considered as most important physiological response that is regulated by PBRs. This regulation of abscission occurs at two very different times in the life and development of a fruit. The first occurs early in or at the start of fruit development and this will be referred to as the flower abscission or chemical thinning period and second period when fruit drop prematurely or drop just as they are entering the development period when they can be harvested.

Observations that auxins delayed leaf petiole abscission lead to the finding in the late 1930s by Gardner et al., (1939) that Naphthalene acetic acid (NAA) and naphthalene acetamide (NAAm) could reduce preharvest drop. Other auxins were tested including 2,4-D (2,4dichlorophenoxyacetic acid) but most proved to be unsatisfactory. Fenoprop (2-[2,4,5trichlorophenoxy]propionic acid) was discovered in the 1950s and proved to be very successful (Southwick et al., 1953) but the registration was dropped in the 1980 s due to fear of contamination with the carcinogen dioxine. The preharvest drop control properties of daminozide (2,2dimethylhydrazide) were recognized in the 1960s soon after its growth control properties were recognized (Edgerton and Hoffman, 1966). This compound was the dominant preharvest drop control compound for over 20 years, not only because of its effectiveness but also because it delayed ripening, increased red color, reduced ethylene production and enhanced flesh firmness. The registration of daminozide for use on apples was withdrawn in 1989 because of health concerns. NAA remained as the lone, viable drop control compound but the drop control properties were relatively short-lived, if two NAA applications were made or if the time between 
application and harvest was delayed, fruit softening and reduced storage life frequently occurred (Smock et al., 1954). As a standalone PBR, NAA could not fill the gap vacated by daminozide.

The ethylene biosynthesis inhibitor aminoethoxyvinylglycine (AVG) was recognized as having stop drop capabilities in 1978 (Bangerth, 1978) but it was not developed for this purpose because daminozide was a very acceptable compound, it possessed several additional assets and an economical way was not known to produce this product and be competitively priced. Following the loss of daminozide Abbott Laboratories (now Valent Biosciences Corp.) initiated drop control studies with AVG and in 1997 and AVG was registered as a drop control compound on apples. It remains today as the prominent drop control PBR.

The most recent candidate as a drop control PBR is 1-methylcyclopropene (1-MCP) (Yuan and Carbaugh, 2007). This is a compound that is released as a gas which then binds irreversibly to ethylene binding sites within the plant. It was first used in the mid 1990s to extend the postharvest life of ornamentals.

It is now used to extend the storage life of apples and the extent of its use, and the impact that it has had on commercial postharvest handling of apples, has been nothing less than remarkable (Watkins, 2006). This compound which normally is administered to apples as a gas in an enclosed space has been formulated so that it can be sprayed on trees. It is a most effective drop control compound on apples and the sprayable form has been registered for use as a drop control compound in several countries.

Some of the most exciting work related to the control of preharvest drop on apples is just now emerging from the lab of Yuan at
Virginia Tech and other locations. Combination of NAA with AVG or 1-MCP more effectively control drop than when the individual drop control compounds are used. Further, these combinations were recognized to more effectively suppress genes responsible for ethylene biosynthesis and cell wall degradation in the abscission zone. The recent and major progress being made in drop control has been achieved by combining molecular biology, good pomology and a better basic understanding of the physiology of abscission.

\section{Role of PGRs in flower abscission - Chemical thinning period}

The inherent characteristic of pome fruit to undergo biennial bearing has been recognized for centuries but practical and meaningful solutions emerged starting in the 1930s. Two separate approaches have been taken in crop load reduction; one is use of hormonal sprays and the second is application of caustic sprays. Auchter and Roberts (1933) used tar oil distillates as caustic materials to remove crop by damaging some blossoms. The compound sodium dinitro-ortho cresylate (DNOC) evolved from this work and remained an important thinner of apples in arid regions until 1990 when registration was discontinued. A flurry of activity followed the loss of DNOC that continues even today. Further details and background on thinning of pome fruit with caustic materials can be found in this volume (Fallahi and Greene, 2010).

Abscission retardation was one of the early physiological responses identified with auxins. Gardener, Batjer and Marth (1945) reported that NAA and NAAm could retard preharvest drop in apples. Armed with this information Burkholder and McCown (1941) attempted to increase fruit set on shy-bearing 'Starking Delicious' using these compounds but instead these PBRs caused abscission rather than preventing it. Work by Batjer, Davidson, 
Southwick and Weeks, Murneek and others in the 1940s and 1950s refined the use of both NAA and NAAm as thinning agents and these compounds are still in common use today. Observations by Batjer and Westwood (1960) of reduced fruit set following the use of the newly introduced insecticide carbaryl (1naphthyl methylcarbamate) led to general and widespread use of this compound as a fruit thinner that persists today. In some regions carbaryl is the favoured thinner because it is mild, its response is not rate sensitive and over thinning is quite unlikely. Carbaryl is now under regulatory scrutiny, and in some areas including large portions of Europe, it may no longer be available for use.

BA emerged as a chemical thinner candidate in the late 1970s when it was found to be a very effective thinner on 'Winesap' apples, but the active ingredient was not packaged into a thinning product until the 1990s; and even then it appeared as an altered formulation of a previous product that also contained a small amount of GA. Although the amount of GA that was present was small, and seemingly unimportant, its presence altered the thinning activity of BA, making it an erratic product to use. A thinning formulation that contained only BA was introduced several years later and this has proved to be very effective. When combined with carbaryl it is a potent chemical thinner (Greene and Autio, 1994).

ABA has appeared on the horizon as a new and potentially useful chemical thinner. It has been shown to be an effective thinner on both apples and pears (Greene, 2007, 2009). It has the added advantage of also being a naturally occurring plant hormone which should be useful in facilitating product registration and grower acceptance. The mode of action has not been defined but undoubtedly, closing of stomata, thus restricting carbohydrate supply will prove to be a contributing factor.
What progress are we making with chemical thinning? An enormous number of field experiments have been done in an attempt to achieve consistent thinning results. Progress has been hampered because important pieces of the puzzle have been missing, but there is reason to be optimistic. The missing links have been the lack of understanding of basic control points in the abscission process, the absence of a method to predict thinning responses, and sorting out the genes primarily responsible for abscission from the background noise of nonparticipatory genes. We as a scientific community are now making progress. Byers et al., (1991) and other have linked light, temperature and carbohydrates to the abscission process. Bangerth (2004) has linked auxins and more elaborate schemes are surfacing that implicate participation by ABA and ethylene. The development of a computer model Lakso et al., (2008) has incorporated the important environmental signals that affect abscission into a model that quite accurately predicts thinner response and provides guidance in the selection of thinning programs prior to application. We are developing fruit measurement systems that allow prediction of thinner results in about 7 days (Greene et al., 2005). More recently Zhu et al., (2008) have identified specific genes involved in the abscission process and they have shown that activation can be linked to specific PBRs.

Abscission is a complex process that undoubtedly involves several hormones and many enzymes. Hormonal signals upregulate and down-regulate genes to drive this process (Costa et al., 2006).

Critical breakthroughs in understanding and regulating abscission will only occurs increasing fundamental understanding components of the abscission process and by specifically identifying genes that are regulated into action or inaction. 


\section{Role of PGRs in vegetative growth}

Appropriate regulation of vegetative growth is important in pome fruit production since there is an inverse relationship between growth and flowering and excessive vegetative growth negatively impacts fruit quality, postharvest life, and development of an efficient and productive tree structure. Batjer et al., (1964) reported that daminozide could effectively inhibit growth of apple trees. It was an important discovery. Since it could also reduce fruit size, affect fruit shape and increase fruit set, its use for growth control early in the season was generally limited to directed application to the tops of vigorous trees, use on young nonbearing trees or on bearing trees where the crop was partially or completely lost. Daminozide remained a viable option for controlling tree growth until 1989 when its registration was cancelled.

Ethephon was also identified as a very effective growth retardant in the 1960s but its use on bearing trees was limited because it was also a strong fruit thinner (Edgerton and Greenhalgh, 1969). It was used quite extensively in the 1970s and 1980s in combination with daminozide for growth control and increased flowering on nonbearing trees on semi-dwarfing rootstocks (Byers and Barden, 1976). Paclobutrazol and other triazole gibberellin biosynthesis inhibitors were extensively tested in the 1980s.

Paclobutrazol was registered for use as a growth retardant in several countries, but its use has been limited due to long persistence in the tree, concerns about ground water contamination and a negative influence on fruit size in pome fruit (Miller, 1989). There were no viable PBR options for growth control of bearing trees until the gibberellins biosynthesis inhibitor prohexadione-calcium (Pro-Ca) was identified and extensively tested in the early 1990s and eventually registered for use by BASF as the proprietary products Apogee in the US and Canada and Regalis in Europe and elsewhere (Rademacher et al., 2004). ProCa degrades relatively rapidly in the tree necessitating repeat application for season long growth control. This seeming short coming has a distinct advantage since it affords a high degree of growth control via metabolism and reapplication. ProCa must be applied quite early, as soon as sufficient leaf area has emerged for absorption, since it requires about 10 days on pome fruit to start to restrict vegetative growth.

\section{Role of PGRs in enhancing flower bud formation}

Harley et al., (1958) showed that NAA had the intrinsic ability to promote flower bud formation distinct from effects related to thinning. Early the focus on NAA was to enhance flower bud formation by chemical thinning to reduce crop load. In the mid 1960s when daminozide came into general use, it was found that daminozide could enhance flowering when applied after bloom. High rates reduced fruit size so lower rates were used to reduce the impact on fruit size. Ethephon proved to be the most effective promoter of flower bud formation. However, its use on bearing trees was limited because ethephon also caused thinning (Byers, 2003).

Many investigators concluded that a combination of daminozide plus ethephon was the appropriate combination to increase flowering. Because of the thinning response, most of this work focused on influencing flowering on young and nonbearing trees. Enhancement of flowering became a lower priority in the 1980s and 1990s because there was a shift to planting trees propagated on dwarfing rootstocks that tended to be much more precocious thus the need for increased flower formation was diminished. 
Table.1 Effect of pre-sowing seed treatment with bio-regulators

\begin{tabular}{|c|c|c|c|c|c|}
\hline $\begin{array}{l}\text { S. } \\
\text { No. }\end{array}$ & Fruit crop & PBRs & Concentration & Response/effect & Reference \\
\hline 1. & Ber & $\mathrm{GA}_{3}$ & 200 ppm & $\begin{array}{l}\text { Highest } \text { germination } 98.76 \text { and } \\
77.82 \%\end{array}$. & $\begin{array}{l}\text { Hore and Sen, } \\
1994\end{array}$ \\
\hline 2. & Jackfruit & $\mathrm{GA}_{3}$ & $100 \mathrm{ppm}$ & $\begin{array}{l}\text { Highest germination percentage } \\
(95.33 \%) \text {, coefficient of velocity of } \\
\text { germination }(27.67) \text {, tallest plants } \\
(26.78 \quad \mathrm{~cm}) \text {, shortest span of } \\
\text { germination (13 days) and fastest } \\
\text { germination (3.61 days). }\end{array}$ & $\begin{array}{l}\text { Singh et al., } \\
2002\end{array}$ \\
\hline 3. & Guava & $\mathrm{GA}_{3}$ & $3000 \mathrm{ppm}$ & $\begin{array}{l}\text { Enhance the seed germination } \\
(83.2 \%) \text {, plant height, number of } \\
\text { leaves/plant and leaf size }\end{array}$ & $\begin{array}{l}\text { Chandra and } \\
\text { Govind, } 1990\end{array}$ \\
\hline 4. & Aonla & $\mathrm{GA}_{3}$ & $500 \mathrm{ppm}$ & $\begin{array}{l}\text { Highest seed germination }(75.50 \%) \text {, } \\
\text { decrease in mortality percentage } \\
(16.63) \text {, increase in seedling height } \\
(72.94 \mathrm{~cm}) \text {, seedling girth }(0.63 \mathrm{~cm}) \text {, } \\
\text { per cent buddable seedling }(80.44 \%) \\
\text { and early germination ( } 8.0 \text { days) }\end{array}$ & $\begin{array}{l}\text { Rashmi et al., } \\
2007\end{array}$ \\
\hline 5. & $\begin{array}{l}\text { Wood } \\
\text { Apple }\end{array}$ & $\mathrm{GA}_{3}$ & $100-150 \mathrm{ppm}$ & $25 \%$ germination & Yadav, 2016 \\
\hline 6. & $\begin{array}{l}\text { Custard } \\
\text { apple }\end{array}$ & $\mathrm{GA}_{3}$ & $500 \mathrm{ppm}$ & Improved germination & Yadav, 2017 \\
\hline
\end{tabular}

Table.2 Effect of bio-regulators on tree growth of different fruit crops

\begin{tabular}{|c|c|c|c|c|c|c|}
\hline $\begin{array}{l}\text { S. } \\
\text { No. }\end{array}$ & Fruit crop & PBR & Concentration & $\begin{array}{l}\text { Stage of } \\
\text { application }\end{array}$ & Response/effect & Reference \\
\hline 1. & $\begin{array}{l}\text { Peach cv. } \\
\text { Early } \\
\text { Grande }\end{array}$ & Paclobutrazol & $8 \mathrm{ml} /$ tree & $\begin{array}{l}\text { When new } \\
\text { growth is just } \\
\text { initiated (last } \\
\text { week of } \\
\text { February) }\end{array}$ & $\begin{array}{l}\text { Minimum trunk } \\
\text { growth, height } \\
\text { and spread }\end{array}$ & $\begin{array}{l}\text { Chanana } \\
\text { and Gill, } \\
2007\end{array}$ \\
\hline 2. & $\begin{array}{l}\text { Guava cv. } \\
\text { Allahabad } \\
\text { Safeda }\end{array}$ & Ethephon & $1000 \mathrm{ppm}$ & $\begin{array}{l}\text { After pruning } \\
\text { (March) }\end{array}$ & $\begin{array}{l}\text { Minimum tree } \\
\text { height and } \\
\text { canopy volume }\end{array}$ & $\begin{array}{l}\text { Singh and } \\
\text { Bal, } 2007\end{array}$ \\
\hline 3. & $\begin{array}{l}\text { Mango cv. } \\
\text { Alphonso }\end{array}$ & Paclobutrazol & $10 \mathrm{~g}$ a.i./tree & - & $\begin{array}{l}\text { Reduced tree } \\
\text { height, mean } \\
\text { shoot length and } \\
\text { number of } \\
\text { dormant shoots, } \\
\text { and increased } \\
\text { flowering }\end{array}$ & $\begin{array}{l}\text { Murti et } \\
\text { al., } 2001\end{array}$ \\
\hline 4. & $\begin{array}{l}\text { Pear cv. } \\
\text { Bagugosa }\end{array}$ & Paclobutrazol & $10 \mathrm{ml} /$ tree & $\begin{array}{l}\text { Late fall stage } \\
\text { (second week } \\
\text { of February) }\end{array}$ & $\begin{array}{l}\text { Reduced the tree } \\
\text { height and leaf } \\
\text { area }\end{array}$ & $\begin{array}{l}\text { Gupta and } \\
\text { Bisht, } 2005\end{array}$ \\
\hline
\end{tabular}


Table.3 Effect of growth regulators on rooting in cuttings/ stooling

\begin{tabular}{|c|c|c|c|c|c|c|}
\hline $\begin{array}{l}\text { S. } \\
\text { No. }\end{array}$ & $\begin{array}{l}\text { Fruit } \\
\text { crop }\end{array}$ & PBR & Concentration & $\begin{array}{l}\text { Stage of } \\
\text { application }\end{array}$ & Response/effect & Reference \\
\hline 1. & Plum & $\begin{array}{l}\text { IBA + } \\
\text { Ethrel }\end{array}$ & $\begin{array}{l}1000 \mathrm{ppm}+50 \\
\mathrm{ppm}\end{array}$ & $\begin{array}{l}\text { One year } \\
\text { old shoots }\end{array}$ & $\begin{array}{l}\text { Maximum percentage of } \\
\text { rooting }(91.63 \%) \text {, more } \\
\text { number of roots, dry root } \\
\text { weight and also } \\
\text { developed the largest root }\end{array}$ & $\begin{array}{l}\text { Gill and } \\
\text { Daulta, } \\
1996\end{array}$ \\
\hline 2. & $\begin{array}{l}\text { Guava } \\
\text { cv. } \\
\text { Sardar }\end{array}$ & IBA & $7,500 \mathrm{ppm}$ & - & $\begin{array}{l}\text { Maximum percentage of } \\
\text { rooting }(97.80 \%) \text { and } \\
\text { survival } \\
(96.30)\end{array}$ & $\begin{array}{l}\text { Singh et } \\
\text { al., } 1996\end{array}$ \\
\hline
\end{tabular}

Table.4 Effect of bioregulators on flowering in mango

\begin{tabular}{|c|c|c|c|c|c|c|}
\hline $\begin{array}{l}\text { S. } \\
\text { No. }\end{array}$ & $\begin{array}{l}\text { Fruit } \\
\text { crop }\end{array}$ & PBR & $\begin{array}{l}\text { Conce } \\
\text { ntrati } \\
\text { on }\end{array}$ & $\begin{array}{l}\text { Stage of } \\
\text { applicat } \\
\text { ion }\end{array}$ & Response/effect & Reference \\
\hline 1. & $\begin{array}{l}\text { Mango } \\
\text { cv. } \\
\text { Langra }\end{array}$ & $\begin{array}{l}\text { Paclobutr } \\
\text { azol }\end{array}$ & $\begin{array}{l}5 \mathrm{~g} \\
\text { a.i./tree }\end{array}$ & - & $\begin{array}{l}\text { Maximum number of } \\
\text { flowering shoots } / \mathrm{m}^{2} \\
(30.32) \text { and percentage of } \\
\text { flowering } \\
(96.15 \%)\end{array}$ & $\begin{array}{l}\text { Baghel et al., } \\
2004\end{array}$ \\
\hline 2. & $\begin{array}{l}\text { Mango } \\
\text { cv. } \\
\text { Langra }\end{array}$ & NAA & $\begin{array}{l}10 \\
\text { ppm }\end{array}$ & & $\begin{array}{l}\text { Enhancing the growth of } \\
\text { new shoot }(29.66 \mathrm{sq} / \mathrm{m}) \text {, } \\
\text { number of leaves }(32.66) \\
\text { and flower per shoot } \\
(1,490)\end{array}$ & $\begin{array}{l}\text { Singh et al., } \\
2011\end{array}$ \\
\hline 3. & $\begin{array}{l}\text { Mango } \\
\text { cv. } \\
\text { Sunderja }\end{array}$ & $\begin{array}{l}\text { Urea } \\
\text { NAA }\end{array}$ & $\begin{array}{l}6 \%+ \\
150 \\
\text { ppm }\end{array}$ & $\begin{array}{l}\text { Initiation } \\
\text { of } \\
\text { flowerin } \\
\text { g stage }\end{array}$ & $\begin{array}{l}\text { Increasing the total flower } \\
\text { number per panicle and } \\
\text { percentage of } \\
\text { hermaphrodite flowers }\end{array}$ & $\begin{array}{l}\text { Baghel and } \\
\text { Tiwari, } 2003\end{array}$ \\
\hline 4. & $\begin{array}{l}\text { Mango } \\
\text { cv. } \\
\text { Alphonso }\end{array}$ & $\begin{array}{l}\text { Paclobutr } \\
\text { azol }\end{array}$ & $\begin{array}{l}10 \\
\mathrm{ml} / \text { tree }\end{array}$ & - & $\begin{array}{l}\text { Longest panicle }(31.57 \\
\mathrm{cm}) \text {, number of branches } \\
\text { per panicle (13), total } \\
\text { number of flowers per } \\
\text { panicle }(620) \text {, number of } \\
\text { hermaphrodite flowers } \\
(189.67) \text { number of male } \\
\text { flowers (425) and } \\
\text { hermaphrodite flowers } \\
(30.59 \%)\end{array}$ & $\begin{array}{l}\text { Vijayalakshmi } \\
\text { and } \\
\text { Srinivasan, } \\
2002\end{array}$ \\
\hline
\end{tabular}


Table.5 Plant bio-regulators in crop regulation of guava

\begin{tabular}{|c|c|c|c|c|c|c|}
\hline S. No. & Fruit crop & PBR & Concentration & Stage of application & Response/effect & Reference \\
\hline 1. & $\begin{array}{l}\text { Guava cv. } \\
\text { Allahabad Safeda }\end{array}$ & NAA & $250 \mathrm{ppm}$ & 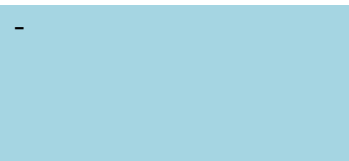 & $\begin{array}{l}\text { Highest deblossoming of the } \\
\text { crop during the rainy season and } \\
\text { the highest yield and fruit } \\
\text { quality during the winter season }\end{array}$ & $\begin{array}{l}\text { Dubey et al., } \\
2002\end{array}$ \\
\hline 2. & Guava cv. Sardar & NAA & 600 ppm & $\begin{array}{l}\text { Full bloom stage } \\
\text { (May) }\end{array}$ & $\begin{array}{l}\text { Maximum winter crop yield } \\
(359.3 \mathrm{q} / \mathrm{ha}) \text { in }\end{array}$ & $\begin{array}{l}\text { Suleman et } \\
\text { al., } 2006\end{array}$ \\
\hline 3. & Guava cv. Sardar & Ethephon & $1800 \mathrm{ppm}$ & - & $\begin{array}{l}\text { Highest yield }(103.98 \mathrm{~kg} / \mathrm{tree}) \text { in } \\
\text { during the winter season }\end{array}$ & $\begin{array}{l}\text { Singh et al., } \\
2000\end{array}$ \\
\hline 4. & $\begin{array}{l}\text { Guava cv. } \\
\text { Allahabad Safeda }\end{array}$ & NAA & 100 ppm & $\begin{array}{l}\text { Initiation of flowering } \\
\text { stage (mid April) }\end{array}$ & $\begin{array}{l}\text { Maximum yield in the winter } \\
\text { season }\end{array}$ & $\begin{array}{l}\text { Das et al., } \\
2007\end{array}$ \\
\hline
\end{tabular}

Table.6 Effect of Auxin on fruit set and development

\begin{tabular}{|c|c|c|c|c|c|c|}
\hline $\begin{array}{l}\text { S. } \\
\text { No. }\end{array}$ & $\begin{array}{l}\text { Fruit } \\
\text { crop }\end{array}$ & PGR & Concentration & $\begin{array}{c}\text { Stage of } \\
\text { application }\end{array}$ & Response/effect & Reference \\
\hline 1. & $\begin{array}{l}\text { Mango } \\
\text { cv. } \\
\text { Sunderja }\end{array}$ & $\begin{array}{l}\text { Urea }+ \\
\text { NAA }\end{array}$ & $6 \%+150 \mathrm{ppm}$ & Pre flowering & $\begin{array}{l}\text { Increasing the total flower } \\
\text { number per panicle and } \\
\text { percentage } \\
\text { hermaphrodite flowers }\end{array}$ & $\begin{array}{l}\text { Baghel and } \\
\text { Tiwari, } 2003\end{array}$ \\
\hline 2. & Apple & $\mathrm{NAA}+\mathrm{BA}$ & $7.5+75 \mathrm{ppm}$ & Full bloom & $\begin{array}{l}\text { Good thinning and good } \\
\text { increase in fruit size }\end{array}$ & Robinson, 2006 \\
\hline 3. & $\begin{array}{l}\text { Guava cv. } \\
\text { L-49 }\end{array}$ & NAA & $10 \mathrm{ppm}$ & At blooming & $\begin{array}{l}\text { Greatest fruit diameter } \\
(5.03 \mathrm{~cm}) \text {, fruit weight } \\
(88.9 \mathrm{~g}) \text {, flesh weight }(83.6 \\
\mathrm{g}) \text {, number of fruits per tree } \\
(666) \text { and fruit yield }(56.9 \\
\mathrm{kg})\end{array}$ & Yadav, 2002 \\
\hline 4. & $\begin{array}{l}\text { Japanese } \\
\text { Plum }\end{array}$ & $\begin{array}{c}2,4- \\
\text { D+NAA }\end{array}$ & $25+30 \mathrm{ppm}$ & $\begin{array}{l}\text { Before pit } \\
\text { hardening }\end{array}$ & $\begin{array}{l}\text { Increase in fruit size } \\
\text { No negative effect on fruit } \\
\text { quality }\end{array}$ & $\begin{array}{l}\text { Stern et al., } \\
\quad 2007\end{array}$ \\
\hline 5. & Cherry & $\begin{array}{c}2,4- \\
\text { D+NAA }\end{array}$ & $25+30 \mathrm{ppm}$ & $\begin{array}{l}\text { Before pit } \\
\text { hardening }\end{array}$ & $\begin{array}{l}\text { Increase in fruit size } \\
\text { No negative effect on fruit } \\
\text { quality }\end{array}$ & $\begin{array}{l}\text { Stern et al., } \\
\quad 2007\end{array}$ \\
\hline 6. & Pear & $\begin{array}{l}\text { NAA } \\
\text { IBA }\end{array}$ & $\begin{array}{l}20 \mathrm{ppm} \\
30 \mathrm{ppm}\end{array}$ & $\begin{array}{l}\text { Young Fruit } \\
\text { period }\end{array}$ & $\begin{array}{l}\text { Enhance fruit growth } \\
\text { Improved final fruit size }\end{array}$ & $\begin{array}{l}\text { Chen et al., } \\
\quad 2012\end{array}$ \\
\hline 7. & Kiwi fruit & $\begin{array}{c}3,5,6- \\
\text { TPA }\end{array}$ & $7,10,14 \mathrm{~g} / \mathrm{ha}$ & $\begin{array}{l}70 \text { days after } \\
\text { full bloom }\end{array}$ & $\begin{array}{l}\text { Treated fruits showed fresh } \\
\text { weight, values higher than } \\
\text { control }\end{array}$ & $\begin{array}{l}\text { Bregoli et al., } \\
2006\end{array}$ \\
\hline 8. & $\begin{array}{l}\text { Mango } \\
\text { cv. } \\
\text { Bombai }\end{array}$ & NAA & $40 \mathrm{ppm}$ & After fruit set & Maximum fruit retension & $\begin{array}{l}\text { Gupta and } \\
\text { Brahmachari, } \\
2004\end{array}$ \\
\hline 9. & Apple & PPA & $0.4 \mathrm{~kg} / \mathrm{ha}$ & Full bloom & $\begin{array}{l}\text { Extended flowering time } \\
\text { increase fruit set }\end{array}$ & $\begin{array}{l}\text { Racsko et al., } \\
2006\end{array}$ \\
\hline 10. & $\begin{array}{l}\text { Delicious } \\
\text { apple }\end{array}$ & NAA & $15 \mathrm{ppm}$ & $\begin{array}{l}11 \mathrm{~mm} \text { KFD } \\
\text { (king fruit } \\
\text { diameter) }\end{array}$ & $\begin{array}{l}\text { Maximum amount of small } \\
\text { fruit }\end{array}$ & $\begin{array}{l}\text { Black et al., } \\
\quad 1995\end{array}$ \\
\hline
\end{tabular}


Table.7 Effect of Gibberellins on fruit set and development

\begin{tabular}{|c|c|c|c|c|c|c|}
\hline $\begin{array}{l}\text { S. } \\
\text { No. }\end{array}$ & $\begin{array}{l}\text { Fruit } \\
\text { crop }\end{array}$ & PBR & Concentration & $\begin{array}{l}\text { Stage of } \\
\text { application }\end{array}$ & Response/effect & Reference \\
\hline 1. & $\begin{array}{l}\text { Mango } \\
\text { cv. } \\
\text { Amrapali }\end{array}$ & $\mathrm{GA}_{3}$ & $\begin{array}{l}100 \text { and } 200 \\
\text { ppm }\end{array}$ & Full bloom & $\begin{array}{l}\text { Maximum fruit } \\
\text { retention, growth, } \\
\text { yield and quality }\end{array}$ & $\begin{array}{l}\text { Rani and } \\
\text { Brahmachari } \\
(2004)\end{array}$ \\
\hline 2. & Pear & $\begin{array}{l}\mathrm{GA}_{4+7} \\
\text { or } \\
\mathrm{GA}_{3}\end{array}$ & 10 to $25 \mathrm{ppm}$ & blossom & $\begin{array}{l}\text { Improve cropping } \\
\text { of pears }\end{array}$ & -- \\
\hline 3. & Pear & $\mathrm{GA}_{3}$ & $11 \mathrm{ppm}$ & At blooming & $\begin{array}{l}\text { Induced fruit } \\
\text { development but led } \\
\text { to the production of } \\
\text { small fruits due to } \\
\text { heavy fruit set. }\end{array}$ & $\begin{array}{l}\text { Knight and } \\
\text { Browning } \\
\text { (1986) }\end{array}$ \\
\hline 4. & Pear & $\begin{array}{l}\mathrm{GA}_{4+7} \\
\mathrm{GA}_{3}\end{array}$ & $\begin{array}{l}3 \% \\
2.7 \%\end{array}$ & $\begin{array}{l}\text { Young Fruit } \\
\text { period }\end{array}$ & $\begin{array}{l}\text { Enhance fruit } \\
\text { growth } \\
\text { Improved final fruit } \\
\text { size }\end{array}$ & $\begin{array}{l}\text { Chen et al., } \\
\text { (2012) }\end{array}$ \\
\hline 5. & Blueberry & $\mathrm{GA}_{3}$ & $0.4 \mathrm{mM}$ & $\begin{array}{l}\text { At full } \\
\text { bloom }\end{array}$ & $\begin{array}{l}\text { Increased fruit set } \\
\text { and decrease fruit } \\
\text { mass }\end{array}$ & $\begin{array}{l}\text { Cano- } \\
\text { Medrano } \\
\text { and Darnell } \\
(1998)\end{array}$ \\
\hline
\end{tabular}

Table.8 Effect of Growth retardant on fruit set and development

\begin{tabular}{|c|c|c|c|c|c|c|}
\hline $\begin{array}{l}\text { S. } \\
\text { No. }\end{array}$ & Fruit crop & PBR & Concentration & $\begin{array}{c}\text { Stage of } \\
\text { application }\end{array}$ & Response/effect & Reference \\
\hline 1. & $\begin{array}{l}\text { Mango cv. } \\
\text { Banganapalli }\end{array}$ & Paclobutrazol & $\begin{array}{l}5 \mathrm{ml} / \text { tree } \\
\text { (twice) }\end{array}$ & $\begin{array}{c}\text { Before bud } \\
\text { break }\end{array}$ & $\begin{array}{l}\text { Maximum } \\
\text { number of fruits } \\
\text { per panicle at } \\
\text { harvesting stage } \\
\text { and number of } \\
\text { fruits/tree }\end{array}$ & $\begin{array}{c}\text { Singh and } \\
\text { Ranganath } \\
\text { (2006) }\end{array}$ \\
\hline 2. & Apple & $\mathrm{PCa}+\mathrm{TDZ}$ & $330+12 \mathrm{ppm}$ & $\begin{array}{l}\text { Petal fall } \\
\text { stage }\end{array}$ & $\begin{array}{l}\text { Increase fruit } \\
\text { set and no of } \\
\text { fruit/tree }\end{array}$ & $\begin{array}{l}\text { Leite } e t \\
\text { al., (2010) }\end{array}$ \\
\hline 3. & Pear & Daminozide & 2000 ppm & & $\begin{array}{l}\text { Increase fruit } \\
\text { set }\end{array}$ & $\begin{array}{l}\text { Costa } e t \\
\text { al., (2006) }\end{array}$ \\
\hline 4. & Pear & $\begin{array}{l}\text { CPPU } \\
6-B A\end{array}$ & $\begin{array}{l}10 \mathrm{ppm} \\
30 \mathrm{ppm}\end{array}$ & $\begin{array}{l}\text { Young fruit } \\
\text { period }\end{array}$ & $\begin{array}{l}\text { Enhance fruit } \\
\text { growth } \\
\text { Improved final } \\
\text { fruit size }\end{array}$ & $\begin{array}{c}\text { Chen et } \\
\text { al., (2012) }\end{array}$ \\
\hline
\end{tabular}


Table.9 Effect of application of plant bio-regulators on different fruit crops

\begin{tabular}{|c|c|c|c|c|}
\hline Crop & Variety & PBRs or other method & Significance & References \\
\hline Grape & Perlette & $\begin{array}{l}\text { Bunch thinning }(40 \%)+ \\
\text { Girdling } 10 \mathrm{DAFS}\end{array}$ & $\begin{array}{l}\text { 1. Increased in berry weight, bunch } \\
\text { weight, reducing sugars and TSS. } \\
2 \text {. Decreased Shot berries, days to } \\
\text { maturity and juice acidity. }\end{array}$ & $\begin{array}{l}\text { Dhillon et } \\
\text { al., (2002) }\end{array}$ \\
\hline \multirow[t]{12}{*}{ Guava } & \multirow{4}{*}{$\begin{array}{l}\text { Allahabad } \\
\text { Safeda and } \\
\text { L-49 }\end{array}$} & NAA@ 100 ppm & $\begin{array}{l}\text { 1. Increase fruit weight in rainy } \\
\text { season. }\end{array}$ & \multirow[t]{12}{*}{$\begin{array}{l}\text { Dass et al., } \\
(2007)\end{array}$} \\
\hline & & NAA@ 200 ppm & Increased TSS in both season. & \\
\hline & & 2,4-D@60 ppm & Average yield increased. & \\
\hline & & K I @ 2\% & $\begin{array}{l}\text { Average fruit weight increased in winter } \\
\text { season. }\end{array}$ & \\
\hline & \multirow[t]{5}{*}{$\begin{array}{l}\text { Allahabad } \\
\text { Safeda }\end{array}$} & NAA@ 100 ppm & $\begin{array}{l}\text { Increased average yield and fruit weight in } \\
\text { rainy season. }\end{array}$ & \\
\hline & & K I @2\% & Increased fruit weight in winter season. & \\
\hline & & K I@1\% & Increased TSS in winter & \\
\hline & & Manual thinning@50\% & Average yield increased. & \\
\hline & & Urea $10 \%$ & Fruit weight and TSS increased & \\
\hline & \multirow[t]{3}{*}{$\mathrm{L}-49$} & 2,4-D@60 ppm & Yield increased. & \\
\hline & & NAA@100ppm & Increased fruit weight in rainy season. & \\
\hline & & K I @ 2\% & Increased fruit weight and yield. & \\
\hline \multirow[t]{10}{*}{ Peach } & \multirow{4}{*}{$\begin{array}{l}\text { Pratap and } \\
\text { Shan-e- } \\
\text { Punjab }\end{array}$} & Ammo. Thiosulphate $2 \%$ at & Increased yield in Shan-e- Punjab. & \multirow{4}{*}{$\begin{array}{l}\text { Saini et al., } \\
\text { (2003) }\end{array}$} \\
\hline & & full bloom & Increased yield in Pratap. & \\
\hline & & & Pratap and Shan-e- Punjab & \\
\hline & & Hand thinning at full bloom & $\begin{array}{l}\text { Increased fruit weight, pulp/ stone ratio, TSS } \\
\text { and enhanced colour, in both cultivars. }\end{array}$ & \\
\hline & \multirow{6}{*}{$\begin{array}{l}\text { Shan-e- } \\
\text { Punjab }\end{array}$} & Urea@6\% & Reduced acidity & \multirow{6}{*}{$\begin{array}{l}\text { Chanana et } \\
\text { al., } \\
(1998)\end{array}$} \\
\hline & & Urea@12\% & Increased TSS & \\
\hline & & Dormex@ 0.25\% & Increased fruit firmness & \\
\hline & & Dormex@ 0.50\% & Increased thinning and fruit weight & \\
\hline & & Hand thinning at full bloom & Reduced acidity & \\
\hline & & $\begin{array}{l}\text { Hand thinning at pit } \\
\text { hardening }\end{array}$ & $\begin{array}{l}\text { Increased TSS/ acid ratio, total sugars, } \\
\text { reducing sugars and fruit firmness. } \\
\text { Decreased days to maturity. }\end{array}$ & \\
\hline \multirow[t]{10}{*}{ Apples } & $\begin{array}{l}\text { Golden } \\
\text { Delicious }\end{array}$ & $\begin{array}{l}\text { DNOC(375ppm)+ NAD ( } 34 \\
\text { ppm) +Ethephon (450 ppm) }\end{array}$ & $\begin{array}{l}\text { Higher Return bloom. } \\
\text { Minimum fruit set/ blossom cluster. }\end{array}$ & \multirow[t]{4}{*}{$\begin{array}{l}\text { Williams } \\
(1978)\end{array}$} \\
\hline & $\begin{array}{l}\text { Spur } \\
\text { Delicious }\end{array}$ & $\begin{array}{l}\text { Carbaryl@1130 gallons/ } \\
\text { ha }\end{array}$ & $\begin{array}{l}\text { Resulted in minimum fruit set and highest } \\
\text { seedless fruits. }\end{array}$ & \\
\hline & \multirow[t]{2}{*}{ Red Gold } & $\begin{array}{l}\text { Manual thinning at fruit dia. } \\
14.10 \mathrm{~mm}\end{array}$ & Increased return bloom. & \\
\hline & & Ethephon@ @ 500 ppm & Increased thinning. & \\
\hline & \multirow{4}{*}{$\begin{array}{l}\text { Golden } \\
\text { Delicious }\end{array}$} & NAA@20ppm & Increased return bloom. & \multirow{4}{*}{$\begin{array}{l}\text { Gautam and } \\
\text { Jindal } \\
\text { (2003) }\end{array}$} \\
\hline & & Ethephon@750ppm & Increased thinning. & \\
\hline & & $\begin{array}{l}\text { NAA }(10 \mathrm{ppm})+\text { Carbaryl } \\
(0.75 \%)\end{array}$ & Increased return bloom in both cultivars. & \\
\hline & & $\begin{array}{l}\text { Manual thinning at fruit dia. } \\
14.79 \mathrm{~mm}\end{array}$ & Increased return bloom. & \\
\hline & \multirow[t]{2}{*}{$\begin{array}{l}\text { Summerred } \\
\text { apple }\end{array}$} & $\begin{array}{l}\text { Ethephon @ } 375 \text { ppm at } \\
20 \% \text { flower open }\end{array}$ & Increased thinning. & \multirow[t]{2}{*}{$\begin{array}{l}\text { Meland } \\
(2011)\end{array}$} \\
\hline & & $\begin{array}{l}\text { Ethephon @ } 625 \mathrm{ppm} \text { at } \\
\text { fruit dia.10 mm. }\end{array}$ & Increased thinning. & \\
\hline
\end{tabular}


Table.10 Effect of application of plant bio-regulators on fruit yield and quality of different fruit crops

\begin{tabular}{|c|c|c|c|c|c|}
\hline Fruit crop & PBR & $\begin{array}{c}\text { Concent } \\
\text { ration }\end{array}$ & $\begin{array}{c}\text { Stage of } \\
\text { application }\end{array}$ & Response/effect & Reference \\
\hline $\begin{array}{l}\text { Guava cv. } \\
\text { Sardar }\end{array}$ & Paclobutrazol & $500 \mathrm{ppm}$ & - & $\begin{array}{c}\text { Maximum fruit length }(6.67 \mathrm{~cm}) \text {, } \\
\text { fruit diameter }(6.74 \mathrm{~cm}), \text { fruit } \\
\text { weight }(179.32 \mathrm{~g}), \text { fruit volume } \\
(172.45 \mathrm{cc}) \text { and thereby maximum } \\
\text { yield }(6.83 \mathrm{~kg} / \text { tree })\end{array}$ & $\begin{array}{l}\text { Jain and } \\
\text { Dashora } \\
\text { (2010) }\end{array}$ \\
\hline $\begin{array}{l}\text { Litchi cv. } \\
\text { Dehradun }\end{array}$ & SADH & $\begin{array}{l}1000 \\
\text { ppm }\end{array}$ & $\begin{array}{l}\text { Initiation of } \\
\text { flowering } \\
\text { stage }\end{array}$ & $\begin{array}{c}\text { Increasing total soluble solids } \\
\text { content (19\%), Total sugars } \\
(18.73 \%) \text { and Non-reducing sugars } \\
(9.56 \%)\end{array}$ & $\begin{array}{l}\text { Sharma et al., } \\
\text { (2005) }\end{array}$ \\
\hline \multirow[t]{2}{*}{$\begin{array}{l}\text { Mango cv. } \\
\text { Langra }\end{array}$} & NAA & 10 ppm & \multirow[t]{2}{*}{ - } & $\begin{array}{c}\text { TSS/acid ratio was significantly } \\
\text { higher }\end{array}$ & \multirow[t]{2}{*}{$\begin{array}{l}\text { Singh et al., } \\
\text { (2011) }\end{array}$} \\
\hline & NAA & 15 ppm & & $\begin{array}{l}\text { Highest ascorbic acid content } \\
\qquad(31.65 \mathrm{mg})\end{array}$ & \\
\hline
\end{tabular}

\section{Physiological effects of auxins}

\begin{tabular}{|c|c|c|}
\hline 1. & $\begin{array}{l}\text { Cell division and } \\
\text { elongation }\end{array}$ & $\begin{array}{l}\text { The primary physiological effects of auxin are cell division and cell } \\
\text { elongation in the shoots. It is important in the secondary growth of stem and } \\
\text { differentiation of xylem and phloem tissues. }\end{array}$ \\
\hline 2. & Apical dominance & $\begin{array}{l}\text { In many plants, if the terminal bud is intact and growing, the growth of lateral } \\
\text { buds just below it remains suppressed. Removal of the apical bud results in the } \\
\text { rapid growth of lateral buds. This phenomenon in which the apical bud dominates } \\
\text { over the lateral buds and does not allow the lateral buds to grow is known as } \\
\text { apical dominance (Thimmann and Skoog, 1933). }\end{array}$ \\
\hline 3. & Root initiation & $\begin{array}{l}\text { The higher concentration of auxin inhibits the elongation of roots but the number } \\
\text { of lateral roots is considerably increased i.e., higher concentration of auxin } \\
\text { induces more lateral branch roots. Application of IAA in lanolin paste (lanolin is } \\
\text { a soft fat prepared from wool and is good solvent for auxin) to the cut end of a } \\
\text { young stem results in an early and extensive rooting. This fact is of great practical } \\
\text { importance and has been widely utilized to promote root formation in } \\
\text { economically useful plants which are propagated by cuttings. }\end{array}$ \\
\hline 4. & $\begin{array}{l}\text { Prevention of } \\
\text { abscission }\end{array}$ & $\begin{array}{l}\text { Natural auxins prevent the formation of abscission layer which cause the fall of } \\
\text { leaves, flowers and fruits in tree plant. }\end{array}$ \\
\hline 5. & Parthenocarpy & $\begin{array}{l}\text { Auxin can induce the formation of parthenocarpic fruits (fruit formation without } \\
\text { pollination and fertilization). In parthenocarpic fruits, the concentration of auxin } \\
\text { in the ovaries is higher than in the ovaries of plants which produce fruits only } \\
\text { after fertilization. In the later cases, the concentration of the auxin in ovaries } \\
\text { increases after pollination and fertilization. }\end{array}$ \\
\hline 6. & Respiration & $\begin{array}{l}\text { Auxin stimulates respiration and there is a correlation between auxin induced } \\
\text { growth and respiration. Auxin may increase the rate of respiration indirectly } \\
\text { through increased supply of ADP by rapidly utilizing ATP in the expanding cells. }\end{array}$ \\
\hline 7. & Callus formation & $\begin{array}{l}\text { Besides cell elongation, auxin may also be active in cell division. In many tissue } \\
\text { cultures, where the callus growth is quite normal, the continued growth of such } \\
\text { callus takes place only after the addition of auxin. }\end{array}$ \\
\hline 8. & Eradication of weeds & $\begin{array}{l}\text { Some synthetic auxins especially } 2,4-\mathrm{D} \text { and } 2,4,5-\mathrm{T} \text { are useful in eradication of } \\
\text { weeds at higher concentrations. }\end{array}$ \\
\hline 9. & $\begin{array}{l}\text { Flowering and sex } \\
\text { expression }\end{array}$ & $\begin{array}{l}\text { Auxins generally inhibit flowering but in pine apple and lettuce it promotes } \\
\text { uniform flowering. }\end{array}$ \\
\hline
\end{tabular}




\section{Physiological effects of gibberellins}

\begin{tabular}{|c|c|c|}
\hline 1. & Seed germination & $\begin{array}{l}\text { Certain light sensitive seeds eg. Lettuce and tobacco show } \\
\text { poor germination in dark. Germination starts vigorously if } \\
\text { these seeds are exposed to light or red light. This requirement } \\
\text { of light is overcome if the seeds are treated with gibberellic } \\
\text { acid in dark. }\end{array}$ \\
\hline 2. & Dormancy of buds & $\begin{array}{l}\text { In temperate regions the buds formed in autumn remain dormant } \\
\text { until next spring due to severe cold. This dormancy of buds can be } \\
\text { broken by gibberellin treatments. In potato also, there is a } \\
\text { dormant period after harvest, but the application of gibberellin } \\
\text { sprouts the refer vigorously. }\end{array}$ \\
\hline 3. & Root growth & $\begin{array}{l}\text { Gibberellins have little or no effect on root growth. At higher } \\
\text { concentration, some inhibition of root growth may occur. The } \\
\text { initiation of roots is markedly inhibited by gibberellins in isolated } \\
\text { cuttings. }\end{array}$ \\
\hline 4. & $\begin{array}{l}\text { Elongation of } \\
\text { internodes }\end{array}$ & $\begin{array}{l}\text { The most pronounced effect of gibberellins on the plant growth is } \\
\text { the elongation of the internodes. Therefore in many plants such as } \\
\text { dwarf pea, dwarf maize etc gibberellins may overcome the genetic } \\
\text { dwarfism. }\end{array}$ \\
\hline 5. & $\begin{array}{l}\text { Bolting and } \\
\text { flowering }\end{array}$ & $\begin{array}{l}\text { In many herbaceous plants, the early period of growth shows } \\
\text { rosette habit with short stem and small leaves. Under short days, } \\
\text { the rosette habit is retained while under long days bolting occurs } \\
\text { i.e. the stem elongates rapidly and is converted into polar axis } \\
\text { bearing flower primordia. This bolting can also be induced in such } \\
\text { plants by the application of gibberellins even under non-inductive } \\
\text { short days. } \\
\text { In Hyoscyamus niger (a long day plant) gibberellin treatment } \\
\text { causes bolting and flowering under non-inductive short days. } \\
\text { While in long day plants the gibberellin treatment usually results } \\
\text { in early flowering. In short day plants, its effects are quite } \\
\text { variable. It may either have no effect or inhibit or may activate } \\
\text { flowering. }\end{array}$ \\
\hline 6. & Parthenocarpy & $\begin{array}{l}\text { Germination of the pollen grains is stimulated by gibberellins; } \\
\text { likewise, the growth of the fruit and the formation of } \\
\text { parthenocarpic fruits can be induced by gibberellin treatment. } \\
\text { In many cases, e.g. pome and stone fruits where auxins have } \\
\text { failed to induce parthenocarpy, the gibberellins have proven to be } \\
\text { successful. Seedless and fleshly tomatoes and large sized seedless } \\
\text { grapes are produced by gibberellin treatments on commercial } \\
\text { scale. }\end{array}$ \\
\hline 7. & $\begin{array}{l}\text { Synthesis of the } \\
\text { enzyme }\end{array}$ & $\begin{array}{l}\text { One important function of gibberellins is to cause the synthesis of } \\
\text { the enzyme amylase in the aleurone layer of the endosperm of } \\
\text { cereal grains during germination. This enzyme brings about } \\
\text { hydrolysis of starch to form simple sugars which are then } \\
\text { translocated to growing embryo to provide energy source. }\end{array}$ \\
\hline
\end{tabular}


Physiological effects of cytokinins

\begin{tabular}{|c|c|c|}
\hline 1. & Cell division & $\begin{array}{l}\text { The most important biological effect of kinetin on plants is to } \\
\text { induce cell division especially in tobacco pith callus, carrot } \\
\text { root tissue, soybean cotyledon, pea callus etc. }\end{array}$ \\
\hline 2. & Cell enlargement & $\begin{array}{l}\text { Like auxins and gibberellins, the kinetin may also induce cell } \\
\text { enlargement. Significant cell enlargement has been observed in } \\
\text { the leaves of Phaseolus vulgaris, pumpkin cotyledons, tobacco } \\
\text { pith culture, cortical cells of tobacco roots etc. }\end{array}$ \\
\hline 3. & $\begin{array}{l}\text { Concentration of } \\
\text { apical dominance }\end{array}$ & $\begin{array}{l}\text { External application of cytokinin promotes the growth of lateral } \\
\text { buds and hence counteracts the effect of apical dominance }\end{array}$ \\
\hline 4. & Dormancy of seeds & $\begin{array}{l}\text { Like gibberellins, the dormancy of certain light sensitive seeds } \\
\text { such as lettuce and tobacco can also be broken by kinetin } \\
\text { treatment. }\end{array}$ \\
\hline 5. & Delay of senescence & $\begin{array}{l}\text { (Richmand - Lang effect) The senescence of leaves usually } \\
\text { accompanies with loss of chlorophyll and rapid breakdown of } \\
\text { proteins. Senescence can be postponed to several days by kinetin } \\
\text { treatment by improving RNA synthesis followed by protein } \\
\text { synthesis. } \\
\text { Richmand and Lang (1957) while working on detached leaves } \\
\text { of Xanthium found that kinetin was able to postpone the } \\
\text { senescence for a number of days. }\end{array}$ \\
\hline$\overline{6 .}$ & Flower induction & $\begin{array}{l}\text { Cytokinins can be employed successfully to induce flowering in } \\
\text { short day plants. }\end{array}$ \\
\hline 7. & Morphogenesis & $\begin{array}{l}\text { It has been shown that high auxin and low kinetin produced only } \\
\text { roots whereas high kinetin and low auxin could promote } \\
\text { formation of shoot buds. }\end{array}$ \\
\hline 8. & $\begin{array}{l}\text { Accumulation and } \\
\text { translocation of } \\
\text { solutes }\end{array}$ & $\begin{array}{l}\text { Plants accumulate solutes very actively with the help of } \\
\text { Cytokinin and also help in solute translocation in phloem. }\end{array}$ \\
\hline 9. & Protein synthesis & $\begin{array}{l}\text { Osborne (1962) demonstrated the increased rate of protein } \\
\text { synthesis due to translocation bys kinetin treatment. }\end{array}$ \\
\hline 10. & Other effects & $\begin{array}{l}\text { Cytokinins provide resistance to high temperature, cold and } \\
\text { diseases in some plants. They also help in flowering by } \\
\text { substituting the photoperiodic requirements. In some cases, they } \\
\text { stimulate synthesis of several enzymes involved in } \\
\text { photosynthesis. Certain light sensitive seeds e.g. Lettuce and } \\
\text { tobacco show poor germination in dark. Germination starts } \\
\text { vigorously if these seeds are exposed to light or red light. This } \\
\text { requirement of light is overcome if the seeds are treated with } \\
\text { gibberellic acid in dark eg. lettuce and tobacco. }\end{array}$ \\
\hline 11. & $\begin{array}{l}\text { Commercial } \\
\text { applications }\end{array}$ & $\begin{array}{l}\text { Cytokinins useful for increasing shelf life of fruits, quickening of } \\
\text { root induction and producing efficient root system, increasing } \\
\text { yield and oil contents of oil seeds like ground nut. }\end{array}$ \\
\hline
\end{tabular}


Physiological effects of Abscisic acid (ABA)

\begin{tabular}{|l|l|l|l|}
\hline 1. & Stomata Closure & $\begin{array}{l}\text { Water shortage brings about increase in ABA level, leading to } \\
\text { stomata closure as a response to water stress. }\end{array}$ \\
\hline 2. & Growth Inhibiters & ABA inhibits shoot growth but has less effect on root growth \\
\hline 3. & GA Counteracts & $\begin{array}{l}\text { ABA counteracts the effect of gibberellins on alpha amylase } \\
\text { synthesis in germinating seeds. }\end{array}$ \\
\hline 4. & Induced Dormancy & ABA affects induction or maintenance of dormancy in seeds. \\
\hline
\end{tabular}

\section{Physiological effects of ethylene}

\begin{tabular}{|l|l|l|}
\hline 1. & Fruit Ripening & $\begin{array}{l}\text { Ethylene in the form of gas helps ripens fruits under natural } \\
\text { conditions. }\end{array}$ \\
\hline 2. & Flower Initiation & $\begin{array}{l}\text { Ethrel (Ethephon) and ACC promote flower initiation in } \\
\text { pineapple. }\end{array}$ \\
\hline 3. & $\begin{array}{l}\text { Leaf and Fruit } \\
\text { Abscission }\end{array}$ & $\begin{array}{l}\text { Accelerates fruit abscission for mechanical harvesting in fruit } \\
\text { crops such as grapes, cherries and citrus. }\end{array}$ \\
\hline 4. & $\begin{array}{l}\text { Inhibit Vegetative } \\
\text { Growth }\end{array}$ & $\begin{array}{l}\text { Ethephon may be used for inhibiting vegetative growth of grape } \\
\text { vines resulting in higher yield and better quality. }\end{array}$ \\
\hline
\end{tabular}

\section{Factors affecting growth promotion and inhibitions}

External factors: The plant growth promotion and inhibition are controlled by internal regulators that are modified according to environmental conditions. The four most important external factors affecting plant growth are light, temperature, water and mineral nutrients.

\begin{tabular}{|c|c|c|}
\hline 1. & Light & $\begin{array}{l}\text { It is ultimate source of energy and the most important ecological factor affecting growth } \\
\text { promotion and inhibition in plants. Variation in quality, intensity and duration of light affect } \\
\text { plant growth. It derives the process of photosynthesis which produces the carbohydrate that } \\
\text { are needed to osmotically retain water in the cell for growth. }\end{array}$ \\
\hline 2. & Temperature & $\begin{array}{l}\text { An optimal temperature is needed for plant growth. Metabolic reactions and plant growth } \\
\text { increases with temperature. Most plant biological activity and growth occurs between } 32^{\circ} \mathrm{F} \\
\text { and } 122^{\circ} \mathrm{F} \text { (Barbour et al., 1987). }\end{array}$ \\
\hline 3. & Water & $\begin{array}{l}\text { Maintenance of the rigidity of the plant tissue is occurring by water. Cell expansion is } \\
\text { controlled by cell turgor pressure, which depends on water. Any deficit in the water supply } \\
\text { reduces the cell turgor pressure and limits cell elongation, resulting in a smaller plant } \\
\text { (Brown, 1995). }\end{array}$ \\
\hline 4. & Mineral nutrients & $\begin{array}{l}\text { Mineral nutrients are needed for the biochemical process of the plant. These constitute the } \\
\text { raw materials required for growth of the plant. Supply the plant necessary mineral ions and } \\
\text { organic substances such as proteins, carbohydrates and others. }\end{array}$ \\
\hline \multicolumn{3}{|c|}{$\begin{array}{l}\text { Internal factor: These are the product of the genetic instructions carried in the plant. These influence the extent and } \\
\text { timing of growth and are mediated by signals of various types transmitted within the cell, between cells, or all around the } \\
\text { plant. Hence, plant growth promotion and inhibition are characterized by high degree of co-ordination and phasing. The } \\
\text { growth of one part is closely related with the growth or activities in other parts of the plant. Such internal coordination } \\
\text { system is maintained by naturally occurring organic compounds referred to as plant hormones or phyto-hormones. }\end{array}$} \\
\hline 1. & Hormone & $\begin{array}{l}\text { The utilization of the nutrients for proper development of the plant is controlled by certain } \\
\text { chemical messengers called hormones. Plant hormones are regulators produced by the plants } \\
\text { which in low concentration regulate a physiological plant process. Hormones usually move } \\
\text { within plant from a site of production to site of action. Phyto-hormones are not carbohydrate } \\
\text { in the sense that carbohydrates are produced and require by the plant in large quantities } \\
\text { while phyto-hormones are produced in small quantities but their effect are pronounced. } \\
\text { Regulation of growth by is actually based on interaction and delicate balance amongst the } \\
\text { various groups of phyto-hormones. }\end{array}$ \\
\hline
\end{tabular}


A new need became very apparent starting in the 1990s when new, unique and better tasting apples were introduced and these were planted extensively. Many of these new varieties had much greater biennial bearing problems than previous standard varieties. 'Honeycrisp' is an excellent example of a new cultivar that is being afflicted by this problem. Many new high density orchards were planted that were highly dependent upon continuous and consistent production to be economically viable. Consequently, the focus on flowering research is to find strategies to increase flowering that do not substantially affect either crop load or fruit maturity. The PBR options are NAA and ethephon, both of which are thinners and they have the potential to advance fruit ripening (Cline, 2008). The general approach at the present time is to use multiple applications of low rates of either NAA or ethephon starting near the end of June drop. Flowering in pome fruit undoubtedly is a very complex and interactive process. Lack of consistent flowering in high density plantings remains an important problem and it needs to be addressed in a more innovative way. Breakthroughs and ultimate regulation of flowering will only come after we have achieved a better understanding of the physiology and mechanisms of flower bud formation. With this knowledge we can then achieve success similar to those we are just now realizing in the understanding in fruit abscission process.

\section{Recent advances in use of plant growth regulators in fruit crops production}

\section{Seed germination}

Seed germination may require gibberellins for the activation of vegetative growth of the embryo. Gibberellin application also activates the alpha amylase synthesis in the aleurone layer where it converts starch to sugar which translocated to growing embryo to provide energy source. Reports on pre-sowing seed treatments of different fruit crops on germination and seedling growth is presented in Table 1.

Pre-sowing treatment with $\mathrm{GA}_{3}$ at $200 \mathrm{ppm}$ was found effective in increasing germination and extending seed longevity of ber cv. Gola. Maximum germination 98.76 and $77.82 \%$ were obtained with $\mathrm{GA}_{3}$ at $200 \mathrm{ppm}$ pretreated seeds sown at one and $17^{\text {th }}$ months after treatment whereas untreated seeds recorded 86.23 and $24.58 \%$ germination. Days to first germination were fewest with $1.0 \%$ thiourea treatment, while the shortest span of germination was obtained with 1000 2000 ppm Cycocel. Incidence of polyembryony was highest with 400 ppm $\mathrm{GA}_{3}$ and 1000 ppm Cycocel (Hore and Sen, 1994).

\section{Control of vigour}

Various growth retardants have been used to restrict the vegetative growth of plant such as AMO 1618, ancymidal, pacloburazol, B-9 (Phosphon D), chlormequat etc (Table 2). The reduction in vegetative growth by growth retardants is due to the systemic inhibition of GAs biosynthesis pathway at the sub-apical meristem, which ultimately reduced cell elongation and rate of cell division and decreased the shoot growth. These growth retardants also inhibit the gibberellin precursor by blocking the oxidation of entkaurene to ent-kaurenoic acid.

Prohexadione-Ca (ProCa) has been evaluated as a growth inhibitor in the vigorous red apple cultivars 'Fuji' and 'Royal Gala'. Greatest inhibition of shoot growth was obtained when ProCa was first sprayed at about $200 \mathrm{mg} \mathrm{L}^{-1}$ from full bloom (FB) up to 12 days after full bloom (DAFB). Shoot regrowth often occurred later in the growing season, and a second application of ProCa was then needed 
to maintain growth inhibition. Inhibition of shoot growth was due mainly to a reduction in internode length. No effects on yield have been found, except for cv. 'Royal Gala', where an increase in crop-load and a decrease in fruit size were recorded. Fruit quality parameters were not affected; but, in cv. 'Fuji', the red colouration of fruit was promoted by ProCa, particularly when repeated sprays of the chemical (at 125 or $250 \mathrm{mg} \mathrm{L}^{-1}$ ) were made. No effects on fruit colour were seen in ProCa-treated cv. 'Royal Gala' trees (Medjdoub et al., 2005).

\section{Root initiation}

A low concentration $\left(10^{-10}\right.$ to $\left.10^{-9} \mathrm{M}\right)$ of auxin promotes the growth of intact roots, whereas a higher concentration $\left(10^{-6} \mathrm{M}\right)$ inhibits root growth. Adventitious roots can arise in a variety of tissue locations from clusters of mature cells that renew their cell division activity. These dividing cells develop into a root apical meristem in a manner somewhat analogous to the formation of lateral roots. In horticulture, the stimulatory effect of auxin on the formation of adventitious roots has been very useful for the vegetative propagation of plants by cuttings (Table 3 ).

Application of 1000 ppm p-hydroxybenzoic acid +5000 ppm IBA results in the maximum rooting percentage $(85 \%)$, number of roots per cutting (56.9), length of longest root (23.2 $\mathrm{cm})$ and survival percentage of cuttings $(80.4 \%)$ in pomegranate cv. Kandhari (Tripathi and Shukla, 2004).

\section{Flowering}

In many woody plants including fruits GA inhibits flower formation. In these cases growth retardants viz. paclobutrazol, SADH which inhibits GA biosynthesis are used to promote flowering such as in pears and mango (Table 4). Application of paclobutrazol helps in restricting the vegetative phase and increasing the reproductive phase of mango (Baghel et al., 2004).

The effects of soil application of $10 \mathrm{ml}$ paclobutrazol and foliar application of 20 ppm NAA, $1 \%$ urea, $1 \%$ potassium nitrate, $200 \mathrm{ppm}$ ethrel and $5000 \mathrm{ppm}$ mepiquat chloride on the flowering of 10-year-old mango cv. Alphanso trees were determined in a field experiment conducted in Coimbatore, Tamil Nadu, India. Soil application with 10 $\mathrm{ml}$ paclobutrazol resulted in the longest panicle $(31.57 \mathrm{~cm})$, number of branches per panicle (13), total number of flowers per panicle (620), number of hermaphrodite flowers (189.67) number of male flowers (425) and hermaphrodite flowers (30.59\%). The male: hermaphrodite flower ratio was highest with application of $1 \%$ potassium nitrate (Vijayalakshmi and Srinivasan, 2002).

\section{Crop regulation}

Plant bio-regulators have been found very effective in thinning flowers and manipulating the cropping season e.g. two sprays of 600800 ppm NAA done in April -May at 15 days interval in Tarai condition at $50 \%$ flowering is effective in regulating the crop in guava. Reduction of crop load of rainy season crop of guava through foliar application of different crop regulating chemicals like urea, 2,4-D, potassium iodide and NAA to increase the yield and quality of winter season crop have been successfully standardized for different agro-climatic zones (Table 5).

The studies were earned out on 20 years old Sardar guava trees in which urea $(10,15$ and $20 \%)$, potassium iodide $(0.5,1.0$ and $2.0 \%)$, maleic hydrazide (1000, 2000 and 3000 ppm), ethephon (600, 1200 and $1800 \mathrm{ppm})$ and NAA (200, 400 and $600 \mathrm{ppm})$ were sprayed during May for crop regulation. All the 
chemicals reduced the yield of rainy season crop significantly over control and subsequently increased the yield of winter season crop. NAA (600 ppm) application produced maximum winter crop yield (359.3 $\mathrm{q} / \mathrm{ha}$ ) followed by the application of 15 per cent urea $(356.2 \mathrm{q} / \mathrm{ha})$. The higher concentrations of urea were found very effective in improving the fruit quality and resulted in maximum TSS (14.0\%), ascorbic acid $(342.2 \mathrm{mg} / 100 \mathrm{~g})$, total sugars $(10.20 \%)$ and pectin $(1.59 \%)$ content in the winter crop. Acidity was significantly reduced by 1800 ppm ethephon during both the seasons. Maximum profit (Rs.1,42,600/ha) was obtained with NAA $600 \mathrm{ppm}$ followed by 15 and 20 per cent urea treatments (Suleman et al., 2006)

\section{Fruit set and development}

It is well known that PBRs are used on many fruit tree to manipulate immature fruit drop, fruit set or size and loosen or remove fruits. The plant bioregulators (PBRs) that contribute in increasing fruit set in different fruit crops have been subject of research and field testing since long. The exogenous application of auxin and gibberellins in most of crosspoolinated fruit crops help in preventing early fruit abscission by substituting to some extent, the normal endogenous production of the same. A part from auxins and gibberellins, the growth retardents, ethylene inhibitors, polyamines and mixture of bioregulators have been found to increase fruit set. However, the mode of action for the above PBRs is yet to be understood clearly. The role of different bioregulators in fruit production is mentioned here under. Pre-pollination applications of putrescine $(1.0$ and $0.01 \mathrm{mM})$ positively affect fruit set in 'Housui' after handpollination (Mora et al., 2004).

Pollination stimulates the development of the ovary and the surrounding tissues leading to the formation of fruit. The changes taking place from the flower to the fruit stage is known as the fruit set. The auxin stimulus leading to fruit set may not only from the pollen but also from the ovary. Pollination stimulates auxin formation in the ovary.

Unpollinated ovaries have only small amounts of auxin. Application of auxin to the fruit increases its size and date of maturity. Application of auxin, late in the life of fruit, hastens maturity and gives fruit of smaller size. The exogenous application of $\mathrm{GA}_{3}$ might have stimulated cell division and cell elongation. Consequently rate of growth and development of fruit was enhanced resulting in larger size of fruits. Gibberellins stimulate the stalk length of seedless grapes to grow longer, thereby alleviating compaction and it promotes elongation of the fruit. A mixture of $\mathrm{GA}_{4+7}$ and BA (Promalin) increase fruit shape, size and quality in Starking Delicious apple. In citrus fruits, gibberellins delay senescence, $\mathrm{GA}_{\mathrm{s}}$ sprays might have triggered auxin level and nullified the action of ABA consequently retained more fruits and allowing the fruits to be left on the tree longer to extend the marked period.

\section{Auxins}

Pear fruit treated with NAA (20 ppm) have strong effect on fruit set and development (Chen et al., 2012). The increase in fruit size as a result of foliar application of NAA might be because it had improved the internal physiology of developing fruit in terms of better supply of water, nutients and other compounds vital for their proper development which resulted in improving size (Jain and Dashora, 2010). The increase in cell size of plums following auxin application at the beginning of pit-hardening, possibly indicates their ability to mobilize carbohydrates uptake and thus enlarge the cell considerably (Stern et al., 2006) (Table 6). 
N-phenyl-phthalamic acid (at $0.4 \quad \mathrm{~kg} / \mathrm{ha}$ Nevirol 60 WP) was sprayed at full bloom.PPA application extended the flowering time of most of the cultivars. Because application was at full bloom, the spray was able to increase the duration of the main bloom and extend flowering time. It was thought that PPA application might increase fruit set in the cases of open and selfpollination (Racsko et al., 2006).

\section{Gibberellins}

Among various growth regulators, the role of gibberellins is definitely more important in the setting of fruits because many experiment with gibberellins spray on the flowers have shown enhancement in fruit set. The gibberellins have been used in improving fruit set with greater promise as compared to auxins in pome fruits. GAs induced fruit set either with mature or immature embryo sacs and differences in fruit-set were related to the stage of nucleus development at the time of application.

Single or multiple applications of $\mathrm{GA}_{3}$ resulted in similar or increased fruit set compared with pollination, and increased fruit set compared with no pollination. $\mathrm{GA}_{3}$ application decrease fruit mass and increased the fruit development period in blueberry (Medrano and Darnell, 1998).

Fruit sprayed with $\mathrm{GA}_{3}$ (100 ppm) have retained maximum number of fruits in Amrapali due to the beneficial effect of GA3 in delaying the formation of abscission layer. GA spray might have triggered auxin level and nullified the action of ABA consequently retained more fruit (Rani and Brahmachari, 2004).

The exogenous application of $\mathrm{GA}_{3}$ might have stimulated cell division and cell elongation. Consequently rate of growth and development of fruit was enhanced resulting in larger size of fruits. Gibberellins stimulate the stalk length of seedless grapes to grow longer, thereby alleviating compaction and it promotes elongation of the fruit. A mixture of $\mathrm{GA}_{4+7}$ and BA (Promalin) increase fruit shape, size and quality in Starking Delicious apple. In citrus fruits, gibberellins delay senescence, $\mathrm{GA}_{\mathrm{s}}$ sprays might have triggered auxin level and nullified the action of ABA consequently retained more fruits and allowing the fruits to be left on the tree longer to extend the marked period.

\section{Growth retardant}

Daminozide (SADH), chlormequat and paclobutrazol have been found effectivein improving fruit set in temperate fruits (Miller, 1989).

A class of inhibitors of gibberellins biosynthesis, the cyclohexanetriones has the ability to control the vegetative growth. This class includes the Prohexadione calcium (PCa), which is particularly effective and has the potential to increase the productivity of apple trees and reduce the need for pruning. Although the apple tree needs 5 to $10 \%$ of flowers fertilized to obtain high production, in adverse pollination conditions or when the flowering intensity is small, it may be necessary the growth regulators application to improve fruit set. Plants treated with PCa+TDZ in petal fall showed the highest values of fruit set and average number of fruits with floral clusters, followed by the plants treated with PCa+TDZ in phenological stage. The results obtained show the mixture PCa+TDZ more effective on increase apple fructification than PCa sprayed alone.

The time of application influence the $\mathrm{PCa}$ response, being the best results obtained when $\mathrm{PCa}$ were sprayed I full bloom stage; Applications of prohexadione calcium with 
thidiazuron had the best results of number of fruits per tree and production per tree when applied in the petal fall stage (Leite et al., 2010).

To assess the effect of chemicals and growth regulators on physical characters of Parbhani Bhusan mango, an experiment was conducted with treatments consisted of NAA at 40, 60, $80 \mathrm{ppm}, \mathrm{KNO}_{3}$ at 2.0, 4.0 and $6.0 \%$, urea at 1 , $1.5,2.0 \%$, triacontanol at 300, 500, and 700 ppm, and distilled water sprayed at flowering, pea and marble stage of fruit development. Triacontanol at $700 \mathrm{ppm}$ showed significantly maximum length $(10.91 \mathrm{~cm})$, breath $(8.91$ $\mathrm{cm})$, volume $(336.58 \mathrm{~cm} 3)$, weight $(330.41 \mathrm{~g})$ and mesocarp (69.92\%). In the case of endocarp (stone), the lowest proportion of endocarp (12.00\%) was recorded in triacontanol at $700 \mathrm{ppm}$ (Shinde et al., 2006).

Several workers conducted the experiments on fruit crops to observe the effects of different method on thinning are summarized in the Table 7.

\section{Fruit quality and yield}

Application of plant bio-regulators resulting in better quality and yield in fruit crops (Table 8) because it improved the internal physiology of developing fruit in terms of better supply of water, nutrients and other compounds vital for their proper growth and development which resulted in improved size, quality and ultimately greater yield (Pandey, 1999).

The effect of urea and growth substances like NAA, Ethrel (ethephon) and Paclobutrazol on the yield and quality of mango cv. Langra was studied. Paclobutrazol at $7.5 \mathrm{~g} /$ tree applied as soil treatment produced the highest yield on both 'off' and 'on' years. Urea 2\% + Ethrel 200 ppm was also found very beneficial. These treatments also improved fruit quality significantly during both years of the study compared with the control (Karuna et al., 2007) (Table 9 and 10).

The plant growth regulators $\left(\mathrm{PGR}_{\mathrm{S}}\right)$ are very important in the integration of developmental activities of plant. It play important role in metabolism and distribution solutes within the plant. Apart from it, they also regulate expression of intrinsic genetic potential of plants. The use of growth regulators has become an important component of agrotechnical practices especially for fruit plants. So far in fruit crops, optimum fruit setting can be maintained by exogenous application of plant growth regulators. The auxin and gibberellins are widely used to control the fruit drop and to improve the quality of fruit.

\section{References}

Abeles, F. 1973. Ethylene in plant biology. Academic Press, London. p.302.

Auchter, E.C. and Roberts, J.W. 1933. Experiments in spraying apples for the prevention of fruit set. Proc. Amer. Soc. Hort. Sci. 30:22-25.

Bagel, B.S. and Tiwari, R. 2003. Individual and integrated effect of urea and NAA on flowering and fruiting of mango (Mangifera indica L.). South Indian Horticulture, 51(1/6): 1-6.

Bagel, B.S. and Tiwari, R. 2003. Individual and integrated effect of urea and NAA on flowering and fruiting of mango (Mangifera indica L.). South Indian Horticulture, 51(1/6): 1-6.

Bagel, B.S., Tiwari, R. and Gupta, N. 2004. Effect of cultar and NAA on flowering and fruiting of mango (Mangifera indica L.) cv Langra. South Indian Horticulture, 52(1/6): 302-304.

Bangerth, F. 1978. The effect of a substituted amino acid on ethylene biosynthesis, respiration, ripening, and preharvest 
drop of apple fruits. J. Amer. Soc. Hort. Sci., 103:401-404.

Bangerth, F.K. 2004. Internal regulation of fruit growth and abscission. Acta Hort., 636:235-248.

Barbour, M.G., Burk, J.H. and Pitts, W.D. 1987. Terrestrial plant ecology. The Benjamin/Cummings Publishing Co., Melno park, California. 634p.

Batjer, L. P. and Marth, P. C. 1945. New materials for delaying fruit abscission of apple. Science. 101: 363-364.

Batjer, L.P. and Westwood, M.N. 1960. 1napthal N-methylcarbonate, a new chemical for thinning apples. Proc. Amer. Soc. Hort. Sci., 75:1-4.

Batjer, L.P., Williams, M.W. and Martin, G.C. 1964. Effects of Ndimethyl amino succinamic acid (B9) on vegetative and fruit characteristics of apples, pears and sweet cherries. Proc. Amer. Soc. Hort. Sci., 85:11-19.

Black, B.L., bukovac, M.J. and Hull, J.Jr. 1995. Effect of spray volume and time of NAA application on fruit size and cropping of Redchief 'Delicious' apple. Scientia Horticulturae 64: 253-264.

Brassins: A new family of plant hormones from rape pollen. Nature, 225:10651066.

Brian, P. and Hemming, H. 1955. The effect of gibberellic acid on shoot growth of pea seedlings. Physiol. Plant., 8:669681.

Brown, R.W. 1995. The water relationship of range plants: adaptations of water deficits. In: Bedunah, D.H. and Sosebee, R.E. (eds.). Wildland plants: physiological ecology and developmental morphology. Society of range management. Denver, $\mathrm{CO}, \mathrm{p}$. 291-413.

Burg, S.P. and Thimann, K.V. 1959. The physiology of ethylene formation in apples. Proc. Nat. Acad. Sci. 45:335344.
Burkholder, C.L. and McCown, M. 1941. Effect of scoring and of $\alpha$-napthyl acetic acid and amide sprays upon fruit set and of the spray on pre-harvest fruit drop. Proc Amer. Soc. Hort. Sci., 38:117-120.

Byers, R.E. 2003. Flower and Fruit thinning and vegetative: fruit balance. p. 409436. In: D.C. Ferree and I.J. Warrington (eds.), Apples botany production and uses. CABI Publishing, Wallingford, UK.

Byers, R.E. and Barden, J.A. 1976. Chemical control of vegetative growth and flowering of non-bearing 'Delicious' apple trees. Hort. Science, 11:506-507.

Byers, R.E., Carbaugh, D.H., Presley, C.N. and Wolf, T.K. 1991. The influence of low light on apple fruit abscission. $J$. Hort. Sci., 66:7-17.

Cano-Medrano, R. and Darnell, R. L. 1998. Cell numbe and cell size in pathenocarpic vs. pollinated blueberry (Vaccinium ashei) fruit. Ann. Bot. 80: 419-425.

Chanana, Y.R. and Gill, K.S. 2007. Effect of soil application of paclobutrazol on growth of Earli Grande peach tree. Indian Journal of Horticulture, 64(2): 211-212.

Chanana, Y.R., kaur, B., kaundal, G.S. and Singh, S. 1998. Effect of flowers and fruit thinning on maturity, yield and quality in peach. Indian J. Hort., 55(4): 323-326.

Chandra, R. and Govind, S. 1990. Gibberellic acid, thio-urea, ethrel and acid treatments in relation to seed germination and seedling growth in guava (Psidium guajava L.). Progressive Horticulture, 22(1-4): 4043.

Chen, X., Bao, J., Chen, Y., Chen, T., Zhang, C. And Huang, X. 2012. Effect of hormone treatment on deformed fruit development in pear. African journal of biotechnology 11(44): 10207-10209. 
Cline, J. 2008. The return bloom of apples as affected by ethephon and naphthalene acetic acid. Compact Fruit Tree, 38(3):40-45.

Cornforth, J.W., Milborrow, B.V., Ryback, G. and Wareing, P.F. 1965. Chemistry and physiology of 'Dormin' in sycamore: Identity of sycamore 'Dormin' with Abscisin II. Nature, 205:1269-1270.

Costa, G., Dal Cin, V. and Ramina, A. 2006. Physiological, molecular and practical aspects of fruit abscission. Acta Hort., 727:301-309.

Crocker, W., Hitchcock, A.E. and Zimmerman, P.W. 1935. Similarities in the effects of ethylene and the plant auxins. Contrib. Boyce Thompson Inst. 7:231-248

Das, B., Nath, V., Jana, B.R., Kumar, S and Dey, P 2007.Evaluation of different methods of crop regulation in guava grown under rainfed plateau conditions of eastern India. Indian Journal of Horticulture, 64(3): 294-299.

Denny, F. E., and Miller, L.P. 1935. Storage temperature and chemical treatments for shortening the rest period of small corms and cormels of gladiolus. CBTI 7(3): 267-294.

Dhillon, W.S., Bindra, A.S. and Brar, B.S. 2002. Effect of nitrogen fertilization on fruit yield, quality and nutrient status of grapevine cv. Perlette. Indian J. Hort. 60(3):208- 213.

Dubey, A.K, Singh, D.B. and Dubey, N. 2002. Crop regulation in guava (Psidium guajava L.) cv. Allahabad Safeda. Progressive Horticulture, 34(2): 200-203.

Edgerton, L.J. and Greenhalgh, W.J. 1969. Regulation of growth, flowering and fruit abscission with 2chloroethylphosphonic acid. J. Amer. Soc. Hort. Sci., 94:11-13.

Edgerton, L.J. and Hoffman, M.B. 1966. Inhibition of fruit drop and color stimulation with $\mathrm{N}$-dimethyl amino succinamic acid. Nature, 299:314-315.

Fallahi, E. and Greene, D.W. 2010. The impact of blossom and post-bloom thinners on fruit set and fruit quality in apples and stone fruit. Acta Hort., 884:179-187.

Gardner, F.E., Marth, P.C. and Batjer, L.P. 1939. Spraying with plant growth substances to control pre-harvest drop of apples. Proc. Amer. Soc. Hort. Sci., 37:415-428.

Gautam, D.R. and Jindal, K.K. 2003. Flowering regulation in pollinizing cultivars of Apple. Haryana J. Hort. Science, 32(3\&4): 156-158.

Gill, D.S. and Daulta, B.S. 1996. Effect of plant growth regulators on rooting of cuttings in plum (Prunus domestica L.). Haryana Journal of Horticultural Sciences, 25(1): 19-22.

Greene, D.W. 2003. Endogenous hormones and bioregulator use on apples. p. 437457. In: D.C. Ferree and I.J. Warrington (eds.), Apples botany production and uses. CABI Publishing, Wallingford, UK.

Greene, D.W. 2007. Effect of abscisic acid (ABA) and benzyladenine (BA) on fruit set and fruit quality of 'McIntosh' apples. Hort. Science, 42(4):908.

Greene, D.W. 2009. Effect of abscisic acid on thinning and return bloom of 'Bartlett' pears. Hort. Science, 44(4):1128.

Greene, D.W. and Autio, W.R. 1994. Combination sprays with benzyladenine to chemically thin spur-type Delicious apples. Hort. Science, 29:887-890.

Greene, D.W., Lakso, A.N. and Robinson, T.L. 2005. Predicting chemical thinner response on apples. Compact Fruit Tree, 38(3):17-20.

Gupta, N.K. and Bist, L.D. 2005. Effect of different planting systems and paclobutrazol on vegetative growth of 
Bagugosa pear. Indian Journal of Horticulture, 62(1): 20-23.

Gupta, R.K. and Brahmachari, V.S. 2004. Effect of foliar application of urea, potassium nitrate and NAA on fruit retention, yield and quality of Mango cv. Bombai. Orissa Journal of Horticulture. 32(2): 7-9.

Harley, C.P., Moon, H.H. and Regeimbal, L.O. 1958. Evidence that post-bloom apple thinning sprays of naphthalene acetic acid increase blossom-bud formation. Proc. Amer. Soc. Hort. Sci., $72: 52-56$

Hore, J.K. and Sen, S.K. 1994. Role of presowing seed treatment on germination, seedling growth and longevity of Ber (Zizyphus mauritiana L.) seeds. Indian Journal of Agriculture Research, 28: 285-289.

Jablonski, J.R. and Skoog, F. 1954. Cell enlargement and cell division in excised tobacco pith tissue. Physiol. Plant., 7:16-24.

Jacobs, W. 1979. Plant hormones and plant development. Cambridge University Press, New York.

Jain, M.C. and Dashora, L.K. 2010. Effect of different plant bio-regulators in relation to fruit quality and yield of guava (Psidium guajava L.) cv. Sardar. Progressive Horticulture, 42(1): 50-53.

Karuna, K., Mankar, A. and Singh, J. 2007. Effect of urea and growth substances on yield and quality of mango cv. Langra. Orissa Journal of Horticulture, 35(1): 67-70.

Knight J.N. and Browning, G. 1986. Regulation of Conference Pear Cropping with Gibberelic Acid and Ethephon or Paclobutrazol. Acta Horticulturae 179: 337-342.

Kogl, F., and Haagen-Smits, A.J. 1931. I. Mitteilung uber pfl anzliche wachstumsstoffe. Uber die vhemie des euchsstoffs. Proceedings Koninklijke
Nederlandse Akademie van Wetenschappen 34:1411-1416.

Kurosawa, E. 1926. Experimental studies on the nature of the substance excreted by the 'bakanae' fungus. Trans Nat Hist Soc Formos 16:213-227.

Lakso, A.N., Robinson, T.L. and Greene, D.W. 2008. Using and apple tree carbohydrate model to understand thinning responses to weather and chemical thinners. Compact Fruit Tree, 41:17-20.

Leite, G.B., Petri, J.L. and Couto, M. 2010. Increasing Apple fruit set on 'Condessa' using Growth regulators. Acta Horticulturae 884: 537-543.

Letham, D. 1963. Zeatin, a faction inducing cell division from Zea mays. Life Sci., 2:569- 573.

Medjdoub, R., Val, J. and Blanco, A. 2005. Inhibition of vegetative growth in red apple cultivars using prohexadionecalcium. Journal of Horticultural Science and Biotechnology, 80(2): 263271.

Medrano, R.C. and Darnell, R.L. 1998. Effect of $\mathrm{GA}_{3}$ and pollination on fruit set development in Rabbiteye Blueberry. Hort Science 33(4): 632-635.

Meland, M., Sekse, L. and Kaiser, C. 2011. Ethephon as a Blossom and Fruitlet Thinner. Affects Crop Load, Fruit Weight, Fruit Quality, and Return Bloom of 'Summerred' Apple (Malus X domestica) Borkh. Hort Science, 46(3): 432-438.

Miller, C.O., Skoog, F., Okumura, F.S., Von Saltza, M.H. and Strong, F.M. 1955. Structure and synthesis of kinetin. $J$. Am. Chem. Soc., 77:2662.

Miller, S.S. 1989. Plant Bioregulators in apple and pear culture. Horticultural Reviews, 10:380-402.

Miller, S.S. and Swietlik, D. 1986. Growth and fruiting responses of deciduous fruit 
trees treated with paclobutrazol. Acta Hort., 179:563-566.

Mitchell, J.E. and Angel, C.R. 1951. The growth-stimulating properties of a metabolic product of Fusarium moniliforme. Phytopathology 41:26-27.

Mora, O.F., Tanabe, K., Tamura, F. And Itai, A. 2004. Effects of putrescine application on fruit set in 'Housui' Japanese pear (Pyrus pyrifolia Nakai). Scientia Horticulturae 104: 265-273.

Murti, G.S.R, Upreti, K.K., Kurian, R.M. and Reddy, Y.T.N. 2001. Paclobutrazol modifies tree vigour and flowering in mango cv. Alphonso. Indian Journal of Plant Physiology, 6(4): 355-360.

Ohkuma, K., Lyon, J.L., Addicott, F.T. and Smith, O.E. 1963. Abscisin II, an abscission acceleratin substance from young cotton fruit. Science, 142:15921593.

Osborne, D.J. 1962. Effect of kinetin on protein and nucleic acids metabolism in Xanthium leaves during senescence. Plant Physiol 37: 595-602.

Pandey, V. 1999. Effect of NAA and GA spray on fruit retention, growth, yield and quality of ber cv. Banarsi Karaka. Orissa Journal of Horticulture, 27(1): 69-73.

Phinney, B.O. 1983. The history of gibberellins. p. 19-52. In: A. Crozier (ed.), The biochemistry and physiology of gibberellins. Vol. 1. Praeger Publ., New York.

Racsko, J., Soltesz, M., Szabo, Z. And Nyeki, J. 2009. The physiological role of the seed set on the flowering and fruit development in some temperate fruit crops. Journal of Plant Reproductive Biology 1(1): 33-42.

Racsko, J., Szabo, M. And Nyeki, J. 2006. Direct and indirect effect of N-phenylphthalamic acid and fertilization on fruit setting and fruit quality parameters of apple (Malus domestica Borkh). Acta Horticulturae727: 209-215.

Rademacher, W., Van Saarloos, K., Garuz Porte, J.A., Riera Forcades, F., Senechai, Y., Andreotti, C., Spinelli, F., Sabatini, E. and Costa, G. 2004. Impact of prohexadione- $\mathrm{Ca}$ on the vegetative and reproductive performance of apple and pear trees. Eur. J. Hort. Sci., 69:221-228.

Rani, R. and Brahmachari, V.S. 2004. Effect of growth substances and calcium compounds on fruit retention, growth and yield of Amrapali mango. Orissa Journal of Horticulture, 32(1): 15-18.

Rashmi, K., Sindhu, S.S., Sehrawat, S.K. and Dudi, O.P. 2007. Germination studies in Aonla (Emblica officinalis G.). Haryana Journal of Horticultural Sciences, 36(12): 9-11.

Richmond, A.E. and Lang, A. 1957. Effect of kinetin on protein content and survival of detached Xanthium leaves. Science $125,650-651$.

Robinson, T.L. 2006. Interaction of Benzyladenine and Naphtalene acetic acid on fruit set, fruit size and Crop value of Twelve Apple cultivars. Acta horiculturae 727: 283-289.

Saini, R.S., Singh, G., Dhaliwal, G.S. and Chanana, Y.R. 2003. Effect of crop regulation in peaches with urea and ammonium thiosulphate on yield and physic-Chemical characteristics of fruits. Haryana J. Hort. Science, 32(3\&4): 187-191.

Sawada, K. 1912. Diseases of agricultural products in Japan. Form Agric Rev. 63:10-16.

Sharma, P., Singh, A.K. and Sharma, R.M. 2005. Effect of plant bio-regulators (PBRs) and micro-nutrients on fruit set and quality of litchi cv. Dehradun. Indian Journal of Horticulture, 62(1): 24-26. 
Shinde, A.K., Patil, B.P., Pujari, K.H., Jadhav, B.B., Chandelkar, A.B. and Kandalkar, M.P. 2008. Investigations on the control of fruit drop in Alphonso mango. Indian Journal of Plant Physiology, 11(1): 93-99.

Singh, D.B. and Ranganath, H.R. 2006. Induction of regular and early fruiting in mango by paclobutrazol under tropical humid climate. Indian Journal of Horticulture, 63(3): 248-250.

Singh, D.B. and Ranganath, H.R. 2006. Induction of regular and early fruiting in mango by paclobutrazol under tropical humid climate. Indian Journal of Horticulture, 63(3): 248-250.

Singh, D.K., Bhattacharya, B. and Mondal, K. 2002. Role of pre-sowing seed treatment with different chemicals on germination behavior and seedling growth of Jackfruit (Artocarpus heterophyllus L.). Environment and Ecology, 20(3): 741-743.

Singh, D.K., Maurya, V.N. and Singh, A.R. 1996. A note on regeneration of guava (Psidium guajava L.) cultivars by stooling with aid of IBA. Haryana Journal of Horticultural Sciences, 25(1): 34-36.

Singh, G., Singh, A.K. and Verma, A. 2000. Economic evaluation of crop regulation treatments in guava (Psidium guajava L.). Indian Journal of Agricultural Sciences, 70(4): 226-230.

Singh, H.J and Bal, J.S. 2007. Effect of pruning and growth regulators on vegetative and fruiting characters of guava planted at different spacing. Haryana Journal of Horticultural Sciences, 36(3/4): 224-227.

Singh, V.R., Mandal, B.K. and Singh, C. 2011. Effect of growth regulators and their concentration on fruiting yield, size and quality of mango cv Langra. Environment-and-Ecology, 29(1A): 306-309.
Smock, R.M., Edgerton, L.J. and Hoffman, M.B. 1954. Some effects of stop drop auxins and respiratory inhibitors on maturity of apples. Proc. Amer. Soc. Hort. Sci., 63:211- 219.

Southwick, F.W., Demoranville, I.D. and Anderson, J.F. 1953. The influence of some growth regulating substances on preharvest drop, color, and maturity of apples. Proc. Amer. Soc. Hort. Sci., 61:155-162.

Stern, R.A., Flaishman, M. And Arie, R.B. 2007. Effect of synthetic auxins on fruit size of five cultivars of japanese plum (Prunus salicina L.). Scientia Horticulturae 112: 304-309.

Stern, R.A., Flaishman, M., Steve, A. And Arie, R.B. 2007. Effect of synthetic auxins on fruit development of 'Bing' cherry (Prunus Avium L.). Scientia Horticulturae 114: 275-280.

Suleman, M., Sharma, J.R., Kumar, R., Pal, R. and Singh, S. 2006. Effect of different chemicals on cropping pattern, and quality of guava cv. Sardar. Haryana Journal of Horticultural Sciences, 35(3/4): 226-227.

Sumiki, Y. A., Kawarada, H., Kitamura, Y., Seta, and N. Takahashi, 1953: The biochemistry of Gibberella fujikuroi. The chemical structure of gibberellin. International Congress for Microbiology, 6th Congress, Rome 1953, Abstracts of Papers, 101-102.

Thimann, K. 1963. Plant Growth Substances: Past, Present and Future. Ann. Rev. Plant Physiol., 14:1-18.

Thimann, K. V. and Skoog, F. 1933. Studies on the growth hormone of plants, part 3. Proc. Nat. Acad. Sci. Wash., 19, 714.

Thimann, K.V. 1969. The auxins. p. 1-45. In: M.B. Wilkins (ed.), Physiology of plant growth and development. McGraw-Hill, New York.

Tripathi, S.N. and Shukla, H.S. 2004. Propagation of pomegranate (Punica 
granatum L.) cultivars by stem cuttings with indole butyric acid and phydroxybenzoic acid. Indian Journal of Horticulture, 61(4): 362-365.

Ueda, J. and Kato, J. 1980. Isolation and identification of a senescencepromoting substance from wormwood (Artemisia absinthium). Plant Physiol., 66:246-249.

Van Overbeek J., Conklin M.E. and Blakeslee A.F. 1941. Factors in coconut milk essential for growth and development of Datura embryos. Science 94: 350.

Vijayalakshmi, D. and Srinivasan, P.S. 2002. Impact of chemicals and growth regulators on induction of flowering in 'off' year mango cv. Alphonso. Orissa Journal of Horticulture, 30(2): 32-34.

Watkins, C.B. 2006. The use of 1methylcyclopropene (1-MCP) on fruits and vegetables. Biotechnol. Adv., 24:389-409.

Went, F.W. 1926. On growth accelerating substances in the coleoptile of Avena sativa. Proceedings Koninklijke Nederlandse Akademie van Wetenschappen. 30:10-19.

Went, F.W. 1928. Wuchsstoff und Wachstum. Receuil des Travaux Botaniques Neerlandais. 25:1-116.

West, C.A. 1973. Biosynthesis of gibberellins. In: Milborrow BV (ed) Biosynthesis and its control in plants. Academic Press, London, New York, pp 473-482.
William, M.W. 1978. Adverse weather and post bloom thinning chemicals can affect seed content and size of Red Delicious apples. Proc. Wash, State hort. Soc.

Yabuta, T. 1935. Biochemistry of the 'bakanae' fungus of rice. Agric Hort (Tokyo) 10:17-22.

Yabuta, T., and Hayashi, T. 1939. Biochemical studies on "Bakanae" fungus of the rice. Part 2. Isolation of "Gibberellin", the active principle which makes the rice seedlings grow slenderly. - J. agric. chem. Soc. Japan. 15: 257-266.

Yadav, P.K. 2002. Effect of urea, borax and NAA on yield parameters of guava (Psidium guajava L.) cv. L-49 in rainy season. Progressive Agriculture, 2(2): 195-196.

Yuan, R. and Carbaugh, D.H. 2007. Effects of NAA, AVG, and 1-MCP on ethylene biosynthesis, preharvest drop, fruit maturity, and quality of 'Golden Supreme' and 'Golden Delicious' apples. Hort. Science, 42:101-105.

Zhu, H., Beers, E.P. and Yuan, R. 2008. Aminoethoxyglycine inhibits fruit abscission induced by naphthalene acetic acid and associated relationships with expression of genes for ethylene biosynthesis, perception, and cell wall degradation in 'Delicious' apples. $J$. Amer. Soc. Hort. Sci., 133(6):727-734.

\section{How to cite this article:}

Tejpal Singh Bisht, Laxmi Rawat, Binayak Chakraborty and Vikas Yadav. 2018. A Recent Advances in Use of Plant Growth Regulators (PGRs) in Fruit Crops - A Review. Int.J.Curr.Microbiol.App.Sci. 7(05): 1307-1336. doi: https://doi.org/10.20546/ijcmas.2018.705.159 